\title{
Stefna í reynd í litlu íslensku hátæknifyrirtæki
}

\author{
Runólfur Smári Steinpórsson og Sandra Margrét Sigurjónsdóttir ${ }^{1}$
}

\begin{abstract}
Ágrip
Greinin fjallar um stefnu íslenska hátæknifyrirtækisins Völku með hliðsjón af kenningum um stefnu í reynd (e. strategy as practice). Rannsóknin er bæði leitandi og lýsandi í senn og er í henni ljósi varpað á pað með hvaða hætti stefna hjá Völku hefur myndast bæði í skipulögðu stefnumiðuðu starfi og eftir sjálfsprottnum leiðum. Með hliðsjón af fræðunum og rannsókninni á Völku er sett fram líkan sem dregur fram kjarnaatriðin í stefnu í reynd. Pessi atriði má sjá í samspili á milli iðkenda (e. practitioners), starfshátta (e. practices) og iðkunarinnar (e. praxis) í stefnumiðuðu starfi Völku. Petta líkan er á frumstigi en pað gefur mynd af hinu stefnumiðaða starfi og tilgátan er að рað geti nýst til frekari rannsókna. Horft er sérstaklega til samspilsins á milli framlags og virkni iðkenda og pess hversu fjölbreyttir og formlegir starfshættir fyrirtækisins eru. Pá var skoðað hvernig umsvif fyrirtækisins hafa próast í samhengi við tengsl pess við viðskiptavini. Hér er um fyrstu rannsókn í röð rannsókna á íslenskum fyrirtækjum að ræða sem ætlað er að varpa ljósi á pað hvernig stefnumiðað starf fer fram í raun og veru í íslenskum fyrirtækjum.
\end{abstract}

\begin{abstract}
The paper informs about strategy development in a small Icelandic high tech company, Valka, with reference to theories and research on Strategy as Practice. The research which is explorative and descriptive is designed as a case study and based on primary data from interviews and secondary data from the company that is studied. The aim of the paper is to reveal the development of strategy in Valka from the start of the company to the present day of the study. The main focus is on how the strategy has developed, who have been involved, through what means and practices this has happened. In light of the Strategy as Practice perspective the focus has been on the practitioners of strategy, the practices and the praxis of strategy in Valka. This study is designed as a pilot study and the results are put forward with the help of a model that has emerged in the research process. The development of Valka's strategy is illustrated, first, through an assessment of who have been involved and with what effort, second, a discussion of how diverse and formal the practices used have been, and third, how the activities of the firm have developed in terms of scope and relations to customers. As a pilot study this work is aimed to be the first of several empirical studies on Strategy as Practice in both private and public organizations in Iceland.
\end{abstract}

${ }^{1}$ Dr. Runólfur Smári Steinpórsson er prófessor í stjórnun og stefnumótun við Viðskiptafræðideild Háskóla Íslands. Sandra Margrét Sigurjónsdóttir er með cand.oecon próf í viðskiptafræði og meistaranemi í stjórnun og stefnumótun við Viðskiptafræðideild Háskóla Íslands, samhliða starfi sínu sem framkvæmdastjóri rekstrarsviðs Landhelgisgæslunnar. Höfundar pakka Helga Hjálmarssyni og öðrum viðmælendum hjá Völku fyrir að gefa kost á rannsókninni. Rannsóknarsjóður Háskóla Íslands fær pakkir fyrir styrk til verkefnisins. Einnig er tveimur nafnlausum ritrýnum pakkað fyrir góðar ábendingar við vinnslu greinarinnar. 
JEL flokkun: M1, L2

Lykilorð: Stefnumótun, iðkendur, starfshæettir, iðkun stefnu, stefna í reynd.

\section{Inngangur}

Á síðustu árum hefur pað sjónarhorn í rannsóknum innan félagsvísinda (e. social sciences) rutt sér rúms par sem viðfangsefnið er rannsakað út frá pví sem gert er, p.e. út frá iðkun pess starfs (e. practice) sem er til skoðunar. Út frá pessu sjónarhorni er leitast við að svara spurningum um pað hvernig gjörðir einstaklinga hafa áhrif og mynda samfélagslega heild (e. social systems) (Golsorkhi, Rouleau, Seidl og Varaa, 2010). Pessi sýn snýst ekki bara um pað sem er hagnýtt (e. practical) heldur tengist petta pví hvernig fólk hegðar sér (e. human agency) og hvernig sú hegðun mótar samfélagið sem við búum í (Vaara og Whittington, 2012). Innan stjórnunarfræða hafa áhrif af pessari bylgju gert vart við sig (Splitter og Seidl, 2011; Rasche og Chia, 2009) og pað ekki síst innan stefnumiðaðrar stjórnunar (e. strategic management) par sem pessi nálgun hefur verið í nokkrum hávegum höfð (Carroll, Levy og Richmond, 2008).

Hér verður pessari nálgun lýst sem stefnu í reynd (e. strategy as practice) og er pá vísað til pess arms stefnumótunarfræðanna sem snýst um stefnumiðaða stjórnun út frá gjörðum og athöfnum í meiri smáatriðum en áður (e. micro) (Golsorkhi o.fl., 2010). Tilgangur rannsókna á pessu sviði er að skýra út hvernig stefnumiðað starf fer fram í raun og veru (Jarzabkowski og Spee, 2009). Að hluta til er horft á stefnumiðað starf með augum félagsfræðinnar (e. sociology) (Venkateswaran og Prabhu, 2010; Jarzabkowski 2004; Whittington 2007) og byggt par m.a. á hugmyndafræði Bourdieu (1990), Giddens (1984), Schatzki (1996), Sztompka (1991) og fleiri um practice theory (Jarzabkowski, 2004; Venkateswaran og Prabhu, 2010).

Að mati Corradi, Gerhardi og Verzelloni (2010) hafa eftirfarandi fræðimenn átt hvað stærstan pátt í að móta pennan arm stefnumótunarfræðanna: Richard Whittington (1996), Paula Jarzabkowski (2003), Gerry Johnson og Julia Balogun ((2004). Talið er að Richard Whittington (1996) hafi verið einna fyrstur til að setja fram hugtakið um stefnu í reynd (e. strategy-as-practice) í grein sinni Strategy as Practice (Golsorkhi o.fl., 2010) og hafa aðrir fylgt í kjölfarið (Vaara og Whittington, 2012; Jarzabkowski, Balogun og Seidl, 2007). Rannsóknir og fræðileg umræða um stefnumiðað starf út frá pessari nálgun hefur skilað sér í auknum fjölda greina í ritrýndum tímaritum og sérheftum auk pess sem haldnar eru ráđstefnur reglulega (Jarzabkowski og Spee, 2009; Golsorkhi o.fl., 2010). Prátt fyrir að hér sé um æ algengari nálgun að ræða er hún enn ung (Chia og McKay, 2007) og ekki er að finna birtar heimildir um rannsóknir á stefnu í reynd í íslensku umhverfi, ef frá er talin rannsókn Vigfúsar Hallgrímssonar (2014).

Tilgangur pessarar greinar er að gefa yfirlit yfir stefnu í reynd sem fræðilega nálgun í stefnumiðuðu starfi og stuðla að rannsóknum og umræðu á íslenskum vettvangi í anda pessarar nálgunar. Sem skref í rannsóknum á stefnu í reynd er hér greint frá raundæmisrannsókn (e. case study) á litlu íslensku fyrirtæki, Völku. Aðalspurningin í rannsókninni er hvernig stefnumiðað starf í fyrirtæki, eins og Völku, hefur farið fram í reynd og yfir tíma, p.e. frá stofnun fyrirtækisins og par til nú. Sérstaklega er horft til framlags og virkni iðkenda, fjölbreytni og formfestu starfshátta og framvindu hins stefnumiðaða starfs í ljósi umsvifa fyrirtækisins og samspilsins við viðskiptavini og umhverfið.

Skipulag greinarinnar er á pann veg að fyrst er gefið fræðilegt yfirlit yfir stefnu í reynd, svo er fjallað um aðferðafræðilega nálgun rannsóknarinnar, pá er yfirlit yfir raundæmisrannsóknina, síðan umræða á grundvelli gagnanna og loks niðurstöður. 


\section{Stefna í reynd, fræðilegt yfirlit}

Segja má að forveri stefnu í reynd úr stefnumótunarfræðunum séu rannsóknir á ferli stefnumiðaðs starfs (e. strategy process research) par sem Henry Mintzberg (1978), Andrew Pettigrew (1985, 1992), Gerry Johnson (1987) og fleiri hafa verið fremstir í flokki (Golsorkhi o.fl., 2010; Whittington og Vaara, 2012). Í kenningum um stefnumiðað starf er alla jafna litið á stefnu sem eitthvað sem fyrirtæki hafi en út frá stefnu í reynd er stefna eitthvað sem fólk gerir (Johnson, Langley, Melin og Whittington, 2007; Whittington, 2006). Раð hefur verið gagnrýnt að rannsóknir á stefnumiðuðu starfi hafi ekki tekið nægilegt tillit til mannlegrar hegðunar (Jarzabkowski o.fl., 2007; Jarzabkowski, 2004) en í sjónarhorni stefnu í reynd felst viðurkenning á að í fyrirtækjum starfar fólk sem hefur tilfinningar, á sér drauma og markmið. Раð eru aðgerðir og hegðun pessa fólks sem hefur áhrif á pað hvernig stefna verður til og hvernig henni vindur fram (Jarzabkowski og Spee, 2009). Leitast er við að svara spurningum um hverjir pað séu sem móti og sinni stefnumiðuðu starfi, hvernig pví sé sinnt, hvaða verkfæri séu notuð og hvaða áhrif pessi atriði hafi á bæði mótun og innleiðingu eða öllu heldur iðkun stefnu (ibid). Mannlegar athafnir og hegðun (e. human act) eru í öndvegi í pessari nálgun (Reckwitz, 2002) og framvindan er alltaf tengd stærra samhengi (Vaara og Whittington, 2012) og pannig má sjá brú á milli pess sem varðar einstaklinga (e. individualism) og pess sem er samfélagslegt (e. societism) (Whittington, 2006). Rannsakendur stefnu í reynd eru að skoða einstaklinga og einstaka aðgerðir peirra en á sama tíma eru peir að finna hvernig athafnir einstaklinganna mynda munstur sem gefur skilning á próuninni í stærra samhengi (Vaara og Whittington, 2012). Áherslan er á pað sem gerist frá degi til dags hjá aðilum með mismunandi aðkomu að fyrirtækjum, bæði innan skipulagsheilda og í tengslum við pær gegnum viðskiptavini eða ráðgjafa (Régner, 2008; Jarzabkowski, 2004).

Fræðimenn hafa einnig lagt áherslu á að stefna í reynd geti tengt saman pað sem gerist í einstaka fyrirtækjum (micro) og pau áhrif sem pað hefur í samfélaginu (macro) (Vaara og Whittington, 2012). Pannig megi líta á stefnumiðað starf sem nokkurs konar sáttmála í samfélaginu, líkt og hjónaband, og rannsaka pað út frá peim sjónarhóli (Whittington, 2007). Rannsóknir á stefnu í reynd hafa gefið ágætan árangur í að skýra út hvernig stefnumiðað starf fer fram en kallað er eftir pví að rannsakendur tengi pessa pekkingu inn í hið stóra samhengi samfélagsins (Vaara og Whittington, 2012; Golsorkhi o.fl., 2010; Jarzabkowski og Spee, 2009). Rannsókn Gomez og Bouty (2011) á próun stefnu í haute-cuisine sýndi fram á að einstaklingurinn hafði áhrif á pað hvernig stefnubreyting varð í atvinnugreininni. Stefna í reynd sem nálgun á rannsóknir á stefnumiðuðu starfi hefur víkkað út viðfangsefni rannsóknanna, beint sjónum manna í meira mæli að félagasamtökum og stofnunum sem ekki starfa í hagnaðarskyni. Pannig er áhuginn ekki lengur bundinn við æðstu stjórnendur og pað með hvaða hætti peir ná efnahagslegum ábata með stefnumiðuðu starfi (Vaara og Whittington, 2012). Pó hafa rannsóknir út frá stefnu í reynd meira beinst að stjórnendum og áhrifum peirra en minna verið skoðað hvaða áhrif starfsmenn almennt hafa á stefnu og iðkun stefnumiðaðs starfs (Égels-Zandén og Rosén, 2014). Rannsóknir á pessu sviði hafa til að mynda beinst að stefnumiðuðu starfi í háskólum (Jarzabkowski, 2003), fjölskyldufyrirtækjum (Nordquist og Melin, 2010), fjölpjóðlegum stórfyrirtækjum (MNE's) (Balogun, Jarzabkowski og Vaara, 2011; Ocasio og Rise, 2008), byggingafyrirtækjum (Sage, Dainty og Brookes, 2012), á hágæða veitingastöðum (Gomez og Bouty, 2011) og yfir í pað að 
skoða með hvaða hætti stjórnir fyrirtækja vinna stefnumiðað starf (Hendry, Kiel og Nicholson, 2010).

Ferilsnálgun (e. process approach) á stefnumiðað starf hefur ekki eingöngu verið talin forveri eða undanfari nálgunarinnar stefnu í reynd (Golsorkhi o.fl., 2010) heldur hafa menn sagt að pessar tvær nálganir séu mjög líkar (Carter, Clegg og Kornberger, 2008). Stefna í reynd hefur jafnvel verið skilgreind sem einn af undirpáttum ferilsnálgunar (Whittington, 2007). Aðrir hafa bent á að pessi armur fræðanna einbeiti sér að pví að skoða hvernig stefna verður til á meðan ferilsnálgunin lúti meira að pví að skoða afkomu og árangur fyrirtækja í pessu samhengi (Jarzabkowski og Spee, 2009) sem og hvernig og hvers vegna stefnumiðað starf próast yfir tíma (Whittington, 2007). Í raun má segja að árangur (e. performance), par á meðal afkoma, hafi verið lykilhugtak í stefnumótunarfræðunum en í yfirlitsgrein Vaara og Whittington (2012) á stefnu í reynd má sjá að í engri peirra greina sem eru til umræðu er verið að fjalla um afkomu (e. economic performance) fyrirtækja með beinum hætti. Par er frammistaða peirra metin á breiðari grundvelli og meiri athygli á pví hvernig iðkendur standa sig eða með hvaða hætti pau verkfæri sem notuð eru koma að gagni (Vaara og Whittingthon, 2012).

Hin klassíska sýn á stefnumiðað starf (e. the classical view) hefur einkennst af pví að stefna skuli vera áformuð (e. deliberate) og innleidd út frá peim áætlunum sem gerðar hafa verið en Henry Mintzberg $(1978,1994)$ setti fram hugtakið sjálfsprottna (e. emergent) stefnu og færði rök fyrir pví að stefna væri ekki alltaf hugsuð fyrirfram, að innleidd stefna væri oft önnur en sú sem lagt var af stað með í upphafi. Prátt fyrir skýr tengsl við hugmyndafræði Mintzbergs um sjálfsprottna stefnu hefur sú hlið stefnu í reynd lítið verið rannsökuð (ÉgelsSanden og Rosén, 2014) ef frá er talin gagnrýnin grein Carters, Cleggs og Kornbergers (2008). Carter o.fl. (2008) setja fram gagnrýni á að stefna í reynd horfi bara til pess sem iðkendur stefnu gera og benda á að kraftar eins og vald (e. power), orðaleikir (e. language games) og tengslanet iðkenda (e. actor network) hafi áhrif á framvindu stefnumiðaðs starfs en Jarzabkowski og Balogun (2009) settu fram líkan um áhrif valds í pessu samhengi. Pá hefur sjónum nýlega verið beint að pví með hvaða hætti aðgerðir sem ekki eru hugsaðar sem stefnumiðuð skref leiða til stefnubreytinga eða annarra áhrifa á stefnumiðað starf í fyrirtækjum (Égels-Zandén og Rosén, 2014). Vaara og Whittington (2012) hafa bent á mikilvægi pess að skoða sjálfsprottna stefnu og hafa rannsóknir á stefna í reynd gefið meiri gaum að pví sem er sjálfsprottið (Ericson, 2014).

Í stefnu sem reynd hafa meginviðfangsefnin verið skilgreind og flokkuð í prennt; í pá sem iðka stefnu (e. practitioners), starfshættina sem stuðst er við (e. practices) og að síðustu sjálfa iðkun stefnunnar (e. praxis), pað er hverjir, með hverju og hvernig stefnu vindur fram og verður að stefnu í reynd (Jarzabkowski og Spee, 2009; Whittington, 2006; Vaara og Whittington, 2012; Jarzabkowski o.fl., 2007). Jafnframt hefur verið litið á stefnu sem sérstakt fag (e. discipline) og samsafn peirra iðkenda sem einkum sinna stefnumiðuðu starfi sem tiltekinn faghóp eða starfsstétt (Whittington, 2007; Corradi o.fl., 2010). Starfsstéttin, sem samanstendur af peim sem iðka stefnumiðað starf bæði úti í fyrirtækjunum en einnig á sviði kennslu og rannsókna, hefur mótandi áhrif á pað með hvaða hætti stefnumiðað starf fer fram og hvernig pað er skilgreint (Whittington, 2007). Iðkendur stefnu eru peir sem setja fram stefnu, móta hana og hafa áhrif á framvindu og innleiðingu hennar. Hér er ekki bara átt við æðstu stjórnendur fyrirtækja heldur einnig millistjórnendur og ýmsa ráðgjafa (Rouleau og Balogun, 2011, Whittington, 2006; Mantere, 2005). Pá hefur verið viðurkennt að starfsmenn á öllum stigum í fyrirtækjum taka pátt í hinu stefnumiðaða starfi og bera kyndil pess á lofti (Mantere, 2005; Kupers, Mantere og Statler, 2013). Iðkun stefnu er pannig skilgreind af 
Jarzabkowski o.fl. (2007) sem samtenging athafna og hegðunar hjá ólíkum einstaklingum og peirra stofnana í samfélaginu sem einstaklingarnir taka pátt í að mynda með hegðun sinni. Fræðimenn geta í rannsóknum sínum bæði litið til nærumhverfisins (e. micro) og skoðað hlutina í stærra samhengi (e. macro), skoðað athafnir og hegðun í tengslum við ákveðið fyrirbæri í tiltekinni atvinnugrein eða skoðað sama fyrirbæri út frá einstaklingi eða tilteknum hópi einstaklinga sérstaklega (Jarzabkowski o.fl., 2007). Með starfsháttum er átt við mynstur athafna sem gerir hópi einstaklinga kleift að vinna samhent og endurtekið sama verkefnið (Jarzabkowski o.fl., 2007; Reckitz, 2002), pannig eru fyrirtæki vöndlar af starfsháttum (e. bundle of practices) sem tengjast saman á einn eða annan hátt og mynda með pví eina heild í hverju fyrirtæki (Schatzki, 2006). Hver starfsháttur endurspeglar einhverja athöfn eins og að elda, að neyta o.s.frv. (Reckitz, 2002), en vísar pó ekki bara til pess sem gert er heldur einnig til undirliggjandi pátta eins og reglna, hefða og venjubundinna atriða sem geta leitt til aðgerða ef svo ber undir (Schatzki, 2006; Jarzabkowski, 2004). Starfshættir hafa að ákveðnu marki tilhneigingu til pess að elta tískustrauma eða tíðaranda og geta sveiflur í hagkerfinu haft áhrif á pað hvernig starfshættir próast, og pannig hafa straumar í samfélaginu (macro) áhrif á fyrirtækin (micro) (Jarzabkowski, 2004). Starfshættir vísa veginn um hvernig stefna er iðkuð pví iðkendur iðka stefnu gegnum starfshættina. Á sama hátt pá móta iðkendur starfshættina við iðkun stefnunnar og pví má segja að pessi prípætta nálgun, iðkendur, starfshættir og iðkun, sé tvinnuð saman (Whittington, 2006).

Nálgun stefnu í reynd sem skóla í stefnumótunarfræðum er að stefna sé bæði ætluð og sjálfsprottin en hún horfir líka til pess að koma auga á pað sem gerist í ferlinu og hefur áhrif á framvinduna en við tökum sem sjálfsögðum hlut (Vaara og Whittington, 2012). Skilningur á pví hvernig iðkendur nota pekkingu á stefnumiðuðu starfi og verkfæri (e. artifacts) stefnumótunarfræða er mikilvægur og hefur stefna í reynd sem nálgun leitt í ljós að iðkendur nota pessi verkfæri með peim hætti sem hentar peim hverju sinni óháð pví hver upphaflegur tilgangur eða fræðilegur bakgrunnur peirra er (Jarzabkowski og Wilson, 2006). Pannig getur glærukynningin sem notuð er í vinnustofu um stefnumiðað starf haft mikla pýðingu og dýpri skilningur á pví með hvaða hætti hún hefur áhrif á mótun, innleiðingu og próun á stefnumiðuðu starfi getur skipt máli (Whittington, 2007). Pá hafa fræðimenn einnig beint sjónum sínum í ríkara mæli að félagslegum atburðum sem verða í tengslum við stefnumiðað starf, eins og fundum (e. strategy meetings), vinnustofum (e. workshops) og dögum par sem vinnuhópar hittast fyrir utan vinnustaðinn (e. awaydays) (Vaara og Whittington, 2012). Slíkir viðburðir virðast að mestu vera leiddir áfram af stjórnendum sjálfum og pátttaka millistjórnenda og annarra starfsmanna er að jafnaði lítil í vinnustofum tengdum stefnumiðuðu starfi (Hodgkinson, Whittington, Johnson og Schwarz, 2006).

Sem lykilpemu í rannsóknum á stefnu í reynd hafa Golorskhi og félagar (2010) bent á eftirfarandi atriði. Í fyrsta lagi er skoðað hvaða starfshættir eru viðhafðir. Í öðru lagi hvernig stefnumiðað starf er sett í samhengi og fær merkingu (e. sensemaking in strategizing). Í priðja lagi hvert hlutverk tungumálsins er í stefnumiðuðu starfi (e. discursive practices of strategy). Í fjórða lagi hvert sé hlutverk hinna ólíku iðkenda, mismunandi verkfæra og fjölbreyttu tækni sem notuð er og í fimmta og síðasta lagi hvaða áhrif vald hefur í tengslum við stefnumiðað starf (Golorskhi o.fl., 2010). Rannsóknir á stefnu í reynd hafa einnig gefið til kynna að stefna myndist með ólíkum hætti í viðskiptaeiningum og deildum fyrirtækja en pegar um er að ræða stefnu sem sett er fram af móðurfélagi eða framkvæmdastjórum. Pannig eru dæmi um stefnu í viðskiptaeiningum sem sprottið hefur fram út frá daglegum verkefnum sem síðan ýtti af stað breytingu á stefnu móðurfélagsins (Régner, 2003). Hendry, Kiel og Nicholson (2010) komust að pví að valdamiklir forstjórar geta hamlað aðkomu stjórnar að 
stefnumiðuðu starfi með pví að halda frá stjórninni upplýsingum og hindra aðgang að lykilfólki. Pá sýndi McCabe (2010) fram á að óræðni (e. ambiguity) í framsetningu á upplýsingum um stefnu og stefnumiðað starf er í einhverjum tilfellum notuð til pess að gefa færi á margvíslegri túlkun sem eykur líkur á pví að fleiri sætti sig við stefnuna. Stefna í reynd eykur skilning á pví hvernig nýsköpun, ímyndunarafl og heppni koma við sögu í að móta óefnislega getu fyrirtækja sem skapar samkeppnisforskot peirra (Régner, 2008) og hefur afhjúpað starfshætti sem hafa annaðhvort hvetjandi eða hamlandi áhrif í stefnumiðuðu starfi (Vaara og Whittington, 2012). Til að mynda eru leiddar líkur að pví að kosningar á fundum um stefnumiðað starf í háskólaumhverfi séu notaðar til pess að drepa niður umræðu fremur en að ýta undir hana (Jarzabkowski og Seidl, 2008). Á hinn bóginn getur vinna með táknræn verkfæri eins og Legókubba ýtt undir samstöðu og sameiginlegan skilning í stefnumiðuðu starfi í framkvæmdastjórn fyrirtækis (Heracleous og Jacobs, 2008). Pá getur orðræða (e. discourse) haft áhrif á framvindu stefnumiðaðs starfs með pví að auka eða minnka, eftir atvikum, lögmæti (e. legitimize/delegitimize) peirra starfshátta sem eru viðhafðir (Mantere og Vaara, 2008). Umræða og texti hafa áhrif á stefnumótun sem hefur aftur áhrif á frekari umræðu og notkun texta (Spee og Jarzabkowski, 2011) og í pví sambandi eru glærukynningar notaðar. Pær auðvelda rökræðu um stefnumiðaðar ákvarðanir og geta virkað sem ákveðið vald fyrir pá aðila sem koma að pví að setja saman upplýsingarnar. Рað er alltaf eitthvert val sem fer fram um hvað pað er sem á að koma fram í glærunum sem ákvörðunin síðan byggir á (Kaplan, 2011).

Stefna í reynd hefur dregið athygli að venjubundnum starfsháttum (e. routine) sem hafa minna verið skoðaðir í hefðbundnum rannsóknum á stefnumiðuðu starfi (Hendry og Seidl, 2003). Í pví samhengi hafa fræðimenn velt fyrir sér hvaða pættir í fari iðkenda eða samspil á milli peirra og hvernig iðkun stefnu í reynd leiðir af sér farsæla breytingu á starfsháttum (Régner, 2008; Hendry og Seidl, 2003). Sú sýn hefur verið sett fram að stefnumiðuð umræða pvingi (e. subjugate) einstaklinga í ákveðna félagslega stöðu (e. social position) (Kupers o.fl., 2012) og í rannsóknum á stefnu í reynd hefur verið rýnt í andstöðu sem kemur upp í tengslum við slíka pvingun (Laine og Vaara, 2007; Kupers o.fl., 2012). Ný verkefni sem sett eru af stað til að framfylgja peirri stefnu sem hefur verið tekin geta framkallað andstöðu (e. resistance) í fyrirtækjum og hafa rannsakendur leitt líkum að pví að orðræða (e. discourse) skipti hér miklu máli (Laine og Vaara, 2007). Í hefðbundnum rannsóknum (e. conventional research) er oft litið fram hjá andstöðu eða horft á hana sem hindrun og óviðeigandi hegðun. Kallað er eftir pví að rannsakendur á stefnu í reynd skoði andstöðuna út frá áhrifum hennar á iðkun, iðkendur og starfshætti í stefnumiðuðu starfi (Golsorkhi o.fl., 2010). Pá gagnrýnir McCabe (2010) að út frá stefnu í reynd hafi ekki verið skoðuð nógu vel aðkoma almennra starfsmanna með hliðsjón af pví að ekki ríkir jöfnuður í fyrirtækjum. Í tengslum við starfshætti hafa menn skoðað hvernig glærukynningar (e. powerpoint) hafa áhrif á stefnumiðað starf (Girdaudeau, 2008; Kaplan, 2011) en ennpá er mikið verk óunnið í að skoða áhrif tækni á stefnumiðað starf (Vaara og Whittington, 2012). Einnig er kallað eftir rannsóknum á pví með hvaða hætti ólík menning hefur áhrif á stefnumiðað starf út frá stefnu í reynd (Golsorkhi o.fl., 2010), auk pess sem Vaara og Whittington (2012) hafa bent á að sjálfsprottin stefna hafi verið lítið skoðuð. Peir benda líka á að mikilvægt sé í pessu sambandi að skoða hvaða endurteknu starfshættir hafa stefnumótandi áhrif á fyrirtæki og möguleika peirra til pess að lifa af. 


\section{Aðferðafræði}

Eins og segir í inngangi pá eru rannsóknir á Íslandi á stefnu í reynd á upphafsreit. Með pað fyrir augum að varpa ljósi á stefnu í reynd var gerð raundæmisrannsókn (e. case study research) á litlu íslensku fyrirtæki. Raundæmisrannsóknir má flokka sem eina tegund af eigindlegum rannsóknaraðferðum (e. qualitiative research method) (Creswell, 2013) sem er vel til pess fallin að kanna atferli (e. behaviours) eða fyrirbæri (e. phenomena) sem lítið er vitað um (Eisenhardt, 1989; Meyer, 2001) og er mikið notuð í ferlisrannsóknum (e. processual research) (Balogun, Huff og Johnson, 2003). Alhæfingargildi slíkra rannsókna byggir ekki á tölfræðilegri úrvinnslu (e. statistical generalization) heldur greiningu og rökfærslu sem miðar að úrbótum á pekkingu (e. analytical generalization) (Yin, 1991) sem getur verið afleiðsla (e. deductive), aðleiðsla (e. inductive) eða tilleiðsla (e. abduction) (Johansson, 2003). Aðrar leiðir sem koma til greina í eigindlegum rannsóknum eru frásagnar- eða orðræðugreining (e. narrative research), fyrirbærafræðileg greining (e. phenomenological research), greining sem miðar að grundaðri kenningu (e. grounded theory research) og mannfræðileg athugun (e. ethnographic research) (Creswell, 2013). Í pessari rannsókn sem hér er greint frá varð raundæmisrannsókn fyrir valinu vegna pess að hún gerir kleift að skoða afmarkað dæmi út frá samhengi pess ofan í kjölinn, ekki síst pegar um er að ræða rannsókn á könnunarstigi (e. exploratory research) (Cooper og Schindler, 2003).

Raundæmisrannsóknir gera kleift að ná djúpum skilningi á fyrirbærinu sem er til rannsóknar og ýkt dæmi (e. extreme cases) geta veitt góða innsýn í orsakir og afleiðingar (Flyvbjerg, 2006). Raundæmisrannsóknir geta jafnframt byggt á einu dæmi eða fleirum (Yin, 1981). Eisenhardt (1989) bendir á pýðingu pess að nota fleiri en eitt dæmi en aðrir hafa lagt áherslu á að skoða eitt dæmi ofan í kjölinn (Dyer og Wilkins, 1991). Rannsóknaraðferðir í raundæmisrannsóknum eru fjölbreyttar og sækja m.a. í kistu tilrauna (e. experimental techniques), í tímatengd gögn (e. time-analysis), í leit að munstri (e. pattern matching) og endurtekningar (e. replication logic) (Welch, Piekkari, Plakoyinnaki og Paavilainenmantymaki, 2011; Yin, 2009). Eins og í mörgum öðrum rannsóknaraðferðum hvort sem pær eru eigindlegar eða megindlegar pá er ekki nein ein forskrift að pví hvernig raundæmisrannsóknir skuli framkvæmdar sem gerir pað að verkum að rannsakendur standa frammi fyrir ýmsum valkostum (Meyer, 2001). Raundæmisrannsóknir hafa vissulega verið gagnrýndar fyrir að vera ekki áreiðanlegar og að pær skorti vísindalega nákvæmni (e. scientific rigor) en á hinn bóginn gefa pær heildstæðari og dýpri skilning á viðfangsefninu sem er til skoðunar (Noor, 2008; Zainal, 2007). Við pessu hefur verið brugðist með mismunandi hætti, allt frá pví að stilla upp agaðri nálgun (Yin, 1981) yfir í að rökstyðja betur gagnsemi nálgunarinnar (Flyvbjerg, 2006).

Í pessari rannsókn var valið að gera raundæmisrannsókn af könnunartoga í peim tilgangi að gera grein fyrir pví með hvaða hætti stefnumiðað starf fer fram í litlu íslensku hátæknifyrirtæki sem er í vexti, með áherslu á stefnu í reynd sem varpar sérstaklega ljósi á iðkun stefnu, iðkendur og starfshætti í stefnumiðuðu starfi. Hér er um að ræða lýsandi raundæmisrannsókn sem byggir á aðleiðslu. Hér að framan hefur verið fjallað um við hvaða aðstæður hentar að velja raundæmisrannsókn sem nálgun í eigindlegum rannsóknum og pær aðstæður eiga við í pessari rannsókn. Pví er pessi aðferð talin kjörin fyrir rannsókn af pví tagi sem hér er um að ræða (Eisenhardt, 1989) par sem raundæmið er sett í samhengi við fræðilega umfjöllun um stefnu í reynd með lýsandi (e. illustrative ) hætti til að veita innsýn inn í pessa nálgun á stefnumiðuðu starfi. 
Við val á raundæminu sem skyldi rannsakað var ákveðið að afmarka rannsóknina við eitt lítið fyrirtæki sem væri í vexti. Talið var að lítið fyrirtæki myndi gera umfang rannsóknarinnar viðráðanlegra og gott aðgengi var lykilatriði. Niðurstaðan var að gera rannsókn á fyrirtækinu Völku. Рað hafði áhrif á valið að annar rannsakenda pekkti nokkuð til fyrirtækisins gegnum tengsl við einn starfsmann pess. Pessi tengsl gerðu pað auðveldara að ná sambandi við forstjóra fyrirtækisins og ýttu mögulega undir pað hversu opin heimild fékkst til rannsóknarinnar. Tengslin höfðu hins vegar ekki nein áhrif á rannsóknina sjálfa og starfsmaðurinn sem tengslin voru við var ekki einn af viðmælendum rannsakenda. Ytra réttmæti rannsóknarinnar (e. external validity) hefði vissulega aukist ef fleiri raundæmi (e. case) hefðu verið könnuð (Eisenhardt, 1989; Yin, 1991) en par sem rannsóknin er af könnunartoga (e. explorative) var talið nægja að styðjast við eitt dæmi (Yin, 1991).

Varðandi valið á litlu fyrirtæki pá hafði pað áhrif að samkvæmt rannsóknum er stefnumiðað starf í litlum fyrirtækjum oft óformlegt, stefnan er sjálfsprottin og fyrirtækin notast lítið við verkfæri stefnumiðaðrar stjórnunar (Stonehouse og Pemberton, 2002). Fræðigreinar og fræðibækur miða oft út frá stórum fjölpjóðlegum fyrirtækjum en aðgangur peirra að fjármagni, mannauði og öðrum gæðum er alla jafna meiri en lítilla fyrirtækja. Lítil fyrirtæki eru 99\% af öllum fyrirtækjum í Evrópu og pau verkfæri sem notast er við í stórum fyrirtækjum nýtast einnig við stefnumótunarvinnu lítilla eininga og geta stuðlað að samkeppnisforskoti peirra (Avram og Kuhne, 2008). Í ljósi pessa töldu höfundar áhugavert að beina sjónum að stefnu í reynd í litlu en vaxandi fyrirtæki.

Áskorun peirra sem vinna að rannsóknum á stefnumiðuðu starfi er að gera ljóst hvaða eining (e. unit of analysis) er til rannsóknar (Johnson o.fl., 2007; Venkateswaran og Prabhu, 2010). Hættan er að falla í pá gryfju að afmarka ekki hvað stefnumiðað starf er og pannig fjalli rannsóknin um allt og um leið ekki neitt (Johnson o.fl., 2007). Hendry og Seidl (2003) lögðu til að atburðir (e. episode) í stefnumiðuðu starfi væru eining til rannsóknar en slíkir atburðir geta verið fundir, rýnifundir (e. reviews) eða annar sá tími sem er tekinn frá til pess að vinna að stefnumiðuðu starfi (Johnson o.fl., 2007). Rannsóknareiningar hafa eðli málsins samkvæmt verið fjölbreytilegar í rannsóknum á stefnu og stefnumiðuðu starfi, frá pví að vera stefnumótunarfundir (Jarzabkowski og Seidl, 2008), vinnuaðferðir stjórnar í stefnumiðuðu starfi (Hendry o.fl., 2010) og yfir í að skoða próun stefnumótunar (e. strategic planning) fyrirtækis yfir langan tíma (Ocasio og Rise, 2008). Nokkrar rannsóknir hafa snúist um að skoða pau tól og tæki sem notast er við í stefnumiðuðu starfi (Kaplan, 2011; Jarrat og Stiles, 2010; Moisander og Stenfors, 2009), pannig eru pær einingar sem eru til rannsóknar af ólíkum toga eins og kemur fram í yfirlitsgrein Vaara og Whittington (2012). Í peirri rannsókn sem hér er greint frá er brugðið ljósi á hvernig stefna próast yfir tíma í íslensku hátæknifyrirtæki og hugað að peim áhrifapáttum sem hafa mótað stefnumiðað starf í fyrirtækinu.

Gagnasöfnun í raundæmisrannsóknum felst yfirleitt í nokkrum mismunandi aðferðum eins og fyrirliggjandi gögnum (e. archives), viðtölum (e. interviews), spurningakönnunum (e. questionnaires) og athugunum (e. observations) (Meyer, 2001; Yin, 1981). Með pví að notast við ólíkar leiðir við gagnaöflun eykst innra réttmæti (e. internal validity) rannsókna (Gibbert, Ruigrok og Wicki, 2008). Pessi rannsókn byggir á hálfstöðluðum viðtölum. Tekin voru sex viðtöl við viðmælendur sem eru í mismunandi hlutverkum í fyrirtækinu. Fyrst var rætt við Helga Hjálmarsson framkvæmdastjóra fyrirtækisins, pá var rætt við Birgi Pór Halldórsson sem sinnir rekstri tölvukerfa, Martin Freyer sem er í hugbúnaðarpróun, Jónmund Eiríksson sem stýrir framleiðslunni, Matthías Jónasson sem er pjónustustjóri og hefur unnið við sölu og að síðustu Einar Björn Jónsson sem er í hugbúnaðarpróuninni. Viðtölin voru tekin í 
trúnaði og tekin upp, pau afrituð og greind í pemu ásamt pví sem rýnt var í fyrirliggjandi gögn. Pær tilvitnanir sem stuðst er við í greininni hafa verið bornar undir viðmælendur. Einnig fengu rannsakendur aðgang að afrakstri stefnumótunarfundar sem haldinn var með starfsmönnum 2012 til greiningar auk pess sem útgefið efni sem og umræða á vefmiðlum um fyrirtækið voru skoðuð. Eðli málsins samkvæmt eru gögn um stefnumiðað starf af margháttuðum toga og ekki um tæmandi yfirlit að ræða í rannsókninni en rannsakendur telja gögnin sem skoðuð voru veita gott yfirlit yfir iðkendur, iðkun stefnu og starfshætti fyrirtækisins. Rannsakendur lögðu sig fram um að gæta að peim páttum sem eru til vitnis um siðlega framkvæmd rannsóknar (Cavana, Delahaye og Sekaran, 2001). Pá voru borin saman munstur (e. pattern matching) úr niðurstöðum pessarar rannsóknar við pá pekkingu sem til er á stefnu í reynd sem einnig eykur á innra réttmæti (Gibbert o.fl., 2008).

\section{Stefnumiðað starf í íslensku hátæknifyrirtæki}

Fyrirtækið sem gaf kost á sér í pessa rannsókn sem hér er greint frá er Valka ehf sem sérhæfir sig í hátæknilausnum fyrir sjávarútveg. Fyrirtækið er ungt og hefur komið fram með lausnir sem hafa vakið athygli bæði hér á Íslandi, í Noregi og víðar. Rannsóknin á Völku hófst á sögu fyrirtækisins, vexti pess og uppbyggingu. Fram komu upplýsingar um formlega stefnu og birtingarmyndir hennar. Sjá mátti áhrif breytinga á mörkuðum á fyrirtækið, afmörkun starfseminnar próast, mikilvægi samvinnu við viðskiptavini, pýðingu liðsandans í fyrirtækinu og atriði sem snertu ferli ákvarðana.

\subsection{Saga fyrirtækisins og próun fyrstu árin}

Fyrirtækið var stofnað árið 2003 af Helga Hjálmarssyni sem er frumkvöðull og framkvæmdastjóri fyrirtækisins. Helgi er vélaverkfræðingur frá Háskóla Íslands og fór í framhaldsnám í vélaverkfræði í Carnegie Mellon háskólanum í Pittsburgh í Bandaríkjunum par sem var áhersla á forritun og tölvuvædda hönnun sem hefur nýst Helga í störfum sínum hjá Völku. Áður starfaði Helgi hjá Marel en ákvað eftir að hafa starfað par í 9 ár að segja upp störfum og fara í sjálfstæðan rekstur. Marel hafði pá hætt við verkefni sem Helgi var að vinna að og snerist um pökkun á ferskum fiskafurðum og eins og Helgi orðar pað sjálfur: „„... mér fannst vera augljóst tækifæri að gera eitthvað par og fór pá bara og stofnaði mitt eigið ...". Hann byrjaði einn í bílskúrnum hjá systur sinni og byggði hægt og rólega upp fyrirtæki sem sérhæfir sig í að próa og markaðssetja tæki og sjálfvirkar lausnir fyrir fiskvinnslu.

Fyrirtækið er í samstarfi við sterka aðila í sjávarútvegi á Íslandi eins og HB Granda og Samherja en fyrsta samstarfsverkefnið var með HB Granda við að útfæra mötun á lausfrysti. Valka fékk með pessu "fljúgandi start” eins og Helgi orðar pað, strax árið 2003 en pað ár seldi fyrirtækið prjár mötunarvélar til HB Granda. Í framhaldinu fékk fyrirtækið styrk frá AVS sjóðnum, rannsóknarsjóði í sjávarútvegi, til pess að vinna að lausn á sjálfvirkri pökkun á fiski sem fyrirtækið vann að með HB Granda (AVS, 2009). Fyrirtækið hefur fengið fleiri styrki til próunar bæði frá AVS og Rannís í gegnum árin sem hafa auðveldað alla próunarvinnu að sögn Helga. Helgi fór strax árið 2004 á sjávarútvegssýninguna í Brussel og var með lítinn bás par.

Par sem tekjur af verkefnum voru stopular á upphafsárunum og Helgi búinn að sjá að uppbygging fyrirtækisins tæki tíma ákvað hann að fá umboð fyrir Solidworks sem er prívíddar hugbúnaður fyrir hönnuði. Með pessu var fjölgað tekjuöflunarleiðum sem gerði fyrirtækinu kleift að starfa án pess að leita frekari fjármögnunar í bili. Síðar hætti fyrirtækið pessari umboðssölu og fór að einbeita sér alfarið að kjarnastarfseminni, p.e. að hanna og 
smíða tæknilausnir fyrir fiskvinnslu. Fyrirtækið hefur í raun vaxið hægt og örugglega eftir pví sem pað hefur próað tæknilausnir til sölu á innlendum og erlendum markaði. Árið 2007 fékk fyrirtækið styrk frá AVS og Rannís og fór í samstarf við Háskólann í Reykjavík við að próa algorithma fyrir vél sem pakkaði fiski í fasta pyngd með minna fráviki en áður hafði pekkst. Petta gerði pað að verkum að nýting viðskiptavina á hráefninu varð töluvert meiri en áður. Í kjölfarið fékk fyrirtækið íslensku sjávarútvegsverðlaunin fyrir pökkunarvélina (Rapid Aligner) og skömmu síðar tókst að ljúka fyrstu sölunni á erlendan markað. Eftir efnahagshrunið sem varð á Íslandi reyndist fyrirtækinu erfiðara að selja tæknilausnir hér sem áttu að leiða af sér framleiðniaukningu. Í kjölfarið var ákveðið að herja á erlendan markað og árið 2009 seldi félagið fiskflokkara (Rapid Aligner) til Noregs og fyrirtækið einbeitti sér að Noregsmarkaði í framhaldinu (Helgi Hjálmarsson, 2013).

Í dag býður fyrirtækið upp á breiða vörulínu, allt frá stökum vogum, innmötunarvélum og flokkurum yfir í heildarkerfi með heilfiskflokkurum, flæðilínum, skurðarvélum ásamt prenturum og pökkunarbúnaði. Pá hefur fyrirtækið próað hugbúnað sem er framleiðslustjórnunar- og pantanakerfi fyrir fiskvinnslur og sölufyrirtæki. Lausnir Völku við sjálfvirkan skurð og flokkun á fiski hafa vakið mikla athygli par sem pær auka nýtingu og verðmæti hráefna umtalsvert en árið 2012 kynnti Valka nýja röntgenstýrða beinaskurðarlínu sem er sú fyrsta sinnar tegundar í heiminum. Eftirspurn eftir sjálfvirkum beinaskurði er mjög mikil og er pví reiknað með að sú lína muni styðja enn frekar undir framtíðarvöxt félagsins. Vélin gerir fiskvinnslum kleift að ná fram nákvæmari skurði og enn betri nýtingu á hráefni en áður. Рað verkefni var unnið í samstarfi við HB Granda og AVS próunarsjóðinn. Fyrirtækið hefur nú selt fimm slíkar vélar. Próunarstarf félagsins hefur skilað pví 5 einkaleyfum og Valka er með umsóknir um fleiri einkaleyfi í pípunum (e. pending). Hjá fyrirtækinu starfa nú 20 starfsmenn í hugbúnaðarpróun, vélahönnun, sölu og markaðsstarfi, við smíðar á tækjum, í stoðpjónustu og stjórnun. Framleiðsla á tækjum Völku er að miklu leyti unnin af íslenskum verktökum en samsetning og prófanir fara fram í húsnæði Völku að Víkurhvarfi í Kópavogi.

Eins og áður sagði hlaut fyrirtækið Íslensku sjávarútvegsverðlaunin árið 2008 fyrir framúrskarandi framleiðslu í fiskvinnslutækni. Pá fékk félagið Vaxtarsprotann árið 2012 og var valið Nýsköpunarfyrirtæki ársins 2013. Auk pess fékk félagið viðurkenningu fyrir vöxt í tengslum við Vaxtarsprotann 2014. Vaxtarsprotinn er viðurkenning sem veitt er á vegum Samtaka iðnaðarins, Rannsóknamiðstöðvar Íslands og Háskólans í Reykjavík og er tilgangurinn að vekja athygli á góðum árangri fyrirtækja sem eru í örum vexti og auka skilning og áhuga á starfsemi peirra (Samtök iðnaðarins, 2012).

Eignarhaldið á félaginu hefur breyst á peim 11 árum sem pað hefur verið starfandi. Til að byrja með var petta einn maður sem átti og rak félagið en árið 2006 fékk Helgi tvo einkafjárfesta með sér inn í félagið og síðar bættist sjá priðji við en samanlagt eiga pessir prír fjárfestar í kringum 20\%. Nýsköpunarsjóður kom að félaginu árið 2008 og er hlutdeild sjóðsins í félaginu 22,8\%. Fjárfestingasjóðurinn Frumtak sem er í eigu Nýsköpunarsjóðs atvinnulífsins og nokkurra lífeyrissjóða fjárfesti í félaginu árið 2011 og á 24\%, Helgi sjálfur á $24 \%$ og svo eru minni hluthafar sem eiga tæp $10 \%$. Peir sem hafa keypt sig inn í félagið hafa hingað til ekki selt sinn hlut og samanstendur stjórnin af fulltrúum pessara aðila.

\subsection{Vöxtur og uppbygging}

Fyrirtækið hefur vaxið jafnt og pétt frá pví pað var stofnað, bæði hvað varðar starfsmannafjölda og veltu. Í raun má segja að eina verulega stökkið sem hefur verið tekið hafi verið árið 2011 pegar fyrirtækið seldi tækjasamstæðu í laxaverksmiðju í Noregi. Pá fór 
veltan úr pví að vera 124 milljónir árið 2010 og í 404 milljónir árið 2011. Á sama tíma fjölgaði starfsmönnum töluvert eða frá pví að vera 7 stöðugildi á ársgrundvelli í pað að vera 11 stöðugildi (Sjá mynd 1).

Hin auknu umsvif virðast hafa haft mikil áhrif á framgang fyrirtækisins og fyrirtækið stefnir á enn frekari vöxt til framtíðar enda er pað mat eigenda og stjórnenda að til pess að eiga möguleika í greininni til framtíðar pá purfi fyrirtækið að vaxa. Раð gætir samt ákveðinnar varkárni eða eins og Jónmundur framleiðslustjóri segir: „,... ekkert að stækka neitt rosalega hratt, bara tekin lítil skref og ekki neinar stórar fjárfestingar, reyna að vera skynsöm í öllu svoleiðis, pað er svona allavega markmiðið hjá mér að fara ekki út í neina vitleysu í pví“. Að sama skapi hefur verið tekin sú stefna að leysa toppa í álagi með verktöku bæði í smíðinni og einnig í hönnun sem og öðru og halda með peim hætti föstum kostnaði í skefjum.

Stækkun fyrirtækisins hefur öll byggst á innri vexti, próun á vélum og tækjum sem hafa aukið við veltu og fjölgun starfsmanna til pess að sinna auknum verkefnum með aukinni sölu. Með pessum vexti hafa verið gerðar breytingar á skipulagi. Árið 2012 voru ráðnir inn millistjórnendur í fyrsta skipti í fyrirtækið og var pá kominn grunnur að starfaskipulagi í félaginu og fyrsti starfsmaður fyrirtækisins á erlendri grund var ráðinn í sumar en hann sinnir sölu- og markaðsmálum í Noregi. Uppbygging stjórnarinnar hefur breyst í gegnum árin með innkomu nýrra hluthafa og urðu ákveðin vatnaskil pegar Frumtak kom inn árið 2011 með nýtt hlutafé. Fram að peim tíma hafði Helgi setið í stjórn félagsins en vék úr stjórninni að kröfu Frumtaks. Petta bendir til pess að hlutverk stjórnarinnar hafi orðið veigameira en pað var áður og jafnfram að vægi frumkvöðulsins minnki pótt öll dagleg stjórnun sé að mestu í höndunum á Helga.

Starfsmenn upplifa vöxtinn sem ákveðna breytingu, vitneskja um hvað er í gangi er ekki eins sjálfsögð og peir óttast að vöxturinn leiði til pess að andrúmsloftið í fyrirtækinu verði ópersónulegra. Að sama skapi upplifa peir að skipulagið er að verða betra á hlutunum, ráðningaferli og verkefnastýring komin í fastari skorður og lykilstarfsmenn fá rými til pess að fara í frí sem var ekki sjálfsagt áður. Petta upplifa starfsmenn jákvætt. Stefna um vöxt virðist vera ofarlega í hugum peirra sem við ræddum við og allir skynja pað að frekari uppbygging sé í farvatninu.

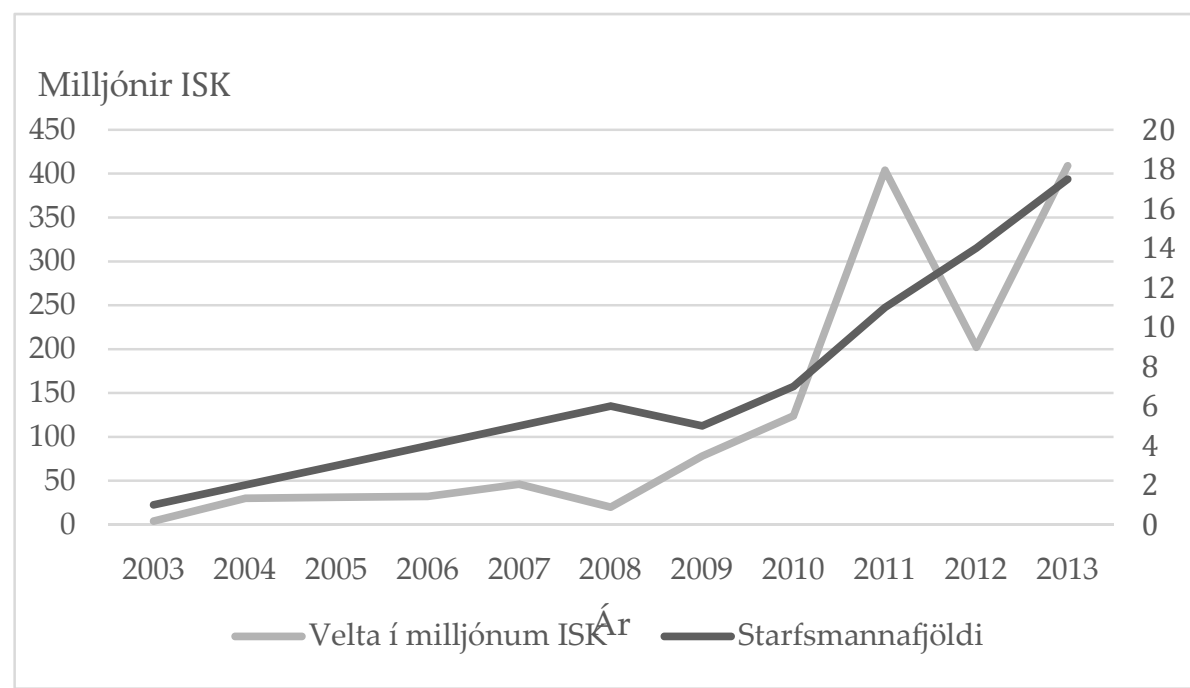

Mynd 1. Yfirlit yfir veltu og starfsmannafjölda. 


\subsection{Formleg stefna og birtingarmyndir hennar}

Á heimasíðu félagsins má sjá að fyrirtækið hefur markað sér framtíðarsýn og sett fram ákveðin gildi. Par kemur fram að framtíðarsýn félagsins er að vera leiðandi í próun og framleiðslu á vinnslukerfum fyrir fiskafurðir. Gildin sem haldið er á lofti eru skilvirkni (efficiency), nýsköpun (innovation) og fullkomnun (perfection) og pá er andrúmloftinu lýst á pann veg að pað fóstri nýsköpun, sköpun og metnað til pess að ná fram frábærum lausnum fyrir viðskiptavinina. Starfsmenn Völku eru sagðir taka öllum áskorunum opnum örmum og að peir séu alltaf með hugann við að gera góða hluti enn betri. Nafnið Valka er dregið af Valkyrjum úr norskri goðafræði og voru skyldur valkyrjanna að velja pær föllnu hetjur sem fengu að berjast við hlið Goðanna (Valka, e.d). Spurður út í nafnið pá segir Helgi:

Ég var að leita að stuttu og laggóðu nafni sem einfalt yrði að bera fram á sem flestum tungumálum. Valka er stytting á valkyrja sem er kröftugur kvenmaður í lauslegri merkingu og markmiðið frá upphafi hefur verið að byggja upp öflugt fyrirtæki!

Fyrirtækið ber öll einkenni pess að vera frumkvöðlafyrirtæki sem er að brjótast út úr pví að velta á frumkvöðlinum og yfir í pað að verða deildaskipt með skýrari verkaskiptingu og stjórnunarhlutverk.

Fyrirtækið hefur farið í formlega stefnumótunarvinnu tvisvar sinnum á peim 11 árum sem pað hefur verið starfandi. Vinnulagið í hinni formlegu vinnu hefur verið pannig аð stjórn félagsins fundar fyrst og leggur ákveðinn grunn að framhaldinu. Раð er ákveðin viðskiptaáætlun sem hefur verið lögð til grundvallar stefnunni sem stjórnin hefur sampykkt og starfsmenn eru meðvitaðir um pessa áætlun sem miðar að vexti á næstu árum. Fyrst var unnin stefnumótun með starfsmönnum árið 2007 par sem rætt var hvar fyrirtækið ætlaði að staðsetja sig á markaði. Sú umræða staðfesti pað að fyrirtækið leggur áherslu á að sérhæfa sig í hágæðavélum og tækjum fyrir fiskvinnslu, bæði hugbúnaði og vélbúnaði.

Árið 2011 var farið með alla starfsmenn á stefnumótunarhelgi í Hveragerði par sem fólki var skipt upp í hópa og gerð var SVÓT greining ásamt frávikagreiningu sem sneri að pví að skoða hvað er gert vel í starfseminni og hvað má bæta. Í pessari vinnu var notast við flettitöflur og glærukynningu. Síðan voru upplýsingarnar settar á rafrænt form til frekari úrvinnslu. Helgi undirbjó vinnustofuna að mestu sjálfur og stýrði umræðunni. Nokkrir starfsmenn gagnrýndu pessa nálgun og töldu að betra hefði verið að fá utanaðkomandi aðila til pess að allir væru á ,jafnréttisgrundvelli“ eins og einn orðaði pað. Pegar gögnin eru skoðuð í samhengi við viðtölin má sjá að margt af pví sem kemur fram í niðurstöðum fundarins hefur verið framkvæmt en pað er hins vegar ekki tilfinning starfsmanna að svo sé. Aðspurðir töldu viðmælendur að ekki hafi mikið komið út úr fundinum. Upplýsingum hefur ekki verið markvisst miðlað til peirra um niðurstöður fundarins og hvernig miðað hefur áfram með verkefnin.

Gildi voru sett fyrir fyrirtækið strax í upphafi og pau sett inn á heimasíðu fyrirtækisins og í kynningarefni pess. Gildin eru sýnileg á vefsíðu og einnig á öllum bæklingum sem fyrirtækið gefur út. Aðspurðir virðast starfsmenn aftur á móti ekki pekkja gildin nema að mjög litlu leyti og er peim ekki haldið á lofti frá degi til dags í fyrirtækinu.

\section{4 Áhrif breytinga á mörkuðum}

Áhrifa breytinga á markaði gætir í peirri stefnu sem fyrirtækið tekur hverju sinni. Hrunið á íslenskum fjármálamarkaði árið 2008 hafði til að mynda í för með sér að íslensk fyrirtæki drógu saman í fjárfestingum. Pessi samdráttur á Íslandi gerði pað að verkum að Valka fór að 
skoða markaðsmöguleika fyrir utan landsteinana í meira mæli en áður. Að vísu hafði alltaf verið stefnan að selja á erlendan markað en tímasetning og kraftur í aðgerðum réðist meira af peim aðstæðum sem höfðu skapast á markaðnum. Helgi lýsir aðdragandanum að sölu á Laxaverksmiðjunni 2011 með eftirfarandi hætti:

\begin{abstract}
....ð pá hafði Marel verið að kaupa upp mikið af fyrirtækjum og pá var eiginlega bara engin samkeppni pannig að pegar pessar verksmiðjur voru að fara að kaupa sér flokkunarbúnað og pökkunarbúnað pá var bara einn sem gat boðið og pað var Marel. Við vorum eiginlega hálfpartinn dregin inn í pennan bransa og pessir kúnnar bara spurðu hvort við gætum ekki bara boðið í petta.
\end{abstract}

Pannig virðist pað hafa verið fyrir prýsting frá markaðnum sem tekin var ákvörðun um að fjölga fólki og velta fyrirtækisins jókst mikið á stuttum tíma eins og áður kom fram. Í upphafi var fyrirtækið að bjóða flokkara fyrir laxaverksmiðjur en fljótlega fundu menn að erfitt var að markaðssetja og selja stakar einingar inn í vinnslukerfi. Markaðurinn kallaði eftir heildstæðum lausnum og pví hefur Valka orðið að próa breiða vörulínu á stuttum tíma. Í lok árs 2011 hrundi markaðsverð á eldislaxi sem gerði pað að verkum að fjárfesting í greininni varð ekki eins og vonir höfðu staðið til en pá var tekin meðvituð ákvörðun um að halda starfsmannafjölda fyrirtækisins óbreyttum og setja kraft í próun sem leiddi af sér vatnsskurðarvélina sem í dag er flaggskip fyrirtækisins.

\title{
4.5 Afmörkun á starfsemi Völku
}

Starfsemi Völku hefur í raun verið stefnumiðuð og pað virðist vera skýrt hver sú afmörkun er í huga allra peirra sem rætt var við. Рað er vísað til pess að sú stefnumörkun hafi verið sett fram af stjórn og í peirri formlegu stefnumótunarvinnu sem fór fram í fyrirtækinu. Helgi lýsir afmörkun starfseminnar pannig:

...nema pað að við vorum búnir að ákveða að við ætluðum að vera í tækja- og hugbúnaði i fiski og við höfum alltaf verið par en höfum ekki farið í eitthvað allt annað, en hvar við endum innan pess pað ræðst svolítið mikið af hvað býðst á markaðnum.

Fyrirtækið hefur nokkuð fylgt pessu og hafnað verkefnum sem falla ekki undir pessa skilgreiningu. Fyrirtækið sérhæfir sig í flóknum lausnum pegar litið er til hugbúnaðar í tengslum við vélar fyrir fiskvinnslu og stefnan hefur orðið skýrari eftir pví sem fyrirtækið hefur vaxið. Áður var verið að vinna í að próa hugbúnaðarlausnir sem standa sjálfstætt en í dag er áherslan á að próa vélarnar og hugbúnaðinn sem tengist peim beint.

Mestur kraftur hefur farið í að sinna landvinnslu en minna að sinna skipum. Pó er ein undantekning á pví pegar seldur var álímingarprentari í eitt fjölveiðiskip. Sú sala var til fyrirtækis sem hafði keypt aðrar vélar af Völku og viðskiptavinurinn kallaði eftir lausn í fjölveiðiskipið sitt. Par með var starfsemin útvíkkuð frá landvinnslu yfir í pað að sinna einnig vinnslu á sjó vegna beiðni frá viðskiptavininum.

Helstu markaðir hafa einnig verið skilgreindir og er pá mest horft til markaðssvæða sem eru nálæg. Matti pjónustustjóri telur upp markaðssvæðin fyrir okkur og lýsir áhrifunum á sölunni í fjölveiðiskipið:

Noregur, Færeyjar, England, Ameríka. Фó að pað séu fyrirspurnir víða að pá verðum við svoldið að standa á bremsunni á meðan við erum ekki stærri en petta. Petta kallar á pjónustu og viðveru á öllum tímum sólahrings. Við vorum í fyrsta sinn að selja svona um borð í fjölveiðiskip [...] pað bara kallar á að vera tilbúinn að svara í síma hvenær 
sem er. Deir eru vinnandi allan sólarhringinn og eru ekkert að spá í hvort menn séu í fasta svefni í landi ....

Pá hafa tilboð verið send til fleiri markaðssvæða en Matti telur upp og Helgi sér petta pannig að önnur markaðssvæði séu innan peirrar stefnu sem fyrirtækið hefur markað sér og nefnir bæði Pólland og Bretland sem dæmi. Helgi lýsir pessu með eftirfarandi hætti:

...svo kannski kemur einhver kúnni núna í Alaska og kaupir og pá mundi færast fókusinn pangað. Баð er ekki pað að við ætluðum ekki að fara pangað, petta er innan okkar stefnu og pá geta hlutimir gerst í aðeins öðruvísi röð en við plönuðum en petta er innan pess ramma sem við erum að gera.

Pannig má sjá hvernig markaðurinn og viðskipti sem fyrirtækið nær að landa hafa áhrif á hvert fyrirtækið beinir kröftum sínum. Áherslan á viðskiptavininn og pjónustu við hann kemur mjög sterkt fram í viðtölunum og má skynja áhrif viðskiptavina á stefnu fyrirtækisins. Pannig lýsir Jónmundur pessu samspili:

...pú setur pér alltaf einhver markmið og reynir að ná peim og svo fer petta mikið eftir kúnnanum, hvað hann vill og við reynum pá bara að fylgja pví. Hann [viðskiptavinurinn] hefur mikið að segja um stefnumótun mundi ég segja, kröfur kúnnans hafa mjög mikið að segja.

Pað er líka ljóst að starfsmenn og stjórnendur sem við töluðum við leggja mikið upp úr pví að pjónusta viðskiptavininn vel og telja að smæð fyrirtækisins auki á sveigjanleika pess til pess að mæta pörfum viðskiptavinanna hratt og örugglega en peir eru tiltölulega fáir ennpá. Matti lýsir pví pannig:

...pað einhvern veginn eru allir svona mjög pjónustulega sinnaðir, pað parf bara að vera í gangi [vísar í tækin sem Valka selur] og við verðum bara að redda pví pannig að pað er mjög auðvelt að hringja í menn og vekja pá á morgnana og fá pá til að hjálpa, menn geta verið í helvítis brasi og pað getur verið um helgi eða á kvöldin eða hvenær sem er.

Mikið er lagt upp úr pví að viðskiptavinurinn sé ánægður og fyrirtækið gengur stundum lengra heldur en samningar gera kröfu um til pess að tryggja að viðskiptavinurinn sé sáttur við vöruna. Pá er mikil áhersla á gæði og frampróun peirra vara sem fyrirtækið framleiðir og Jónmundur framleiðslustjóri sér pað í pessu ljósi:

...okkar vélar eru pannig að við reynum alltaf að próa pær, við reynum alltaf að bæta frá síðustu vél, hvað getum við gert betur, pannig að við reynum alltaf að endurhanna petta eitthvað, líka út frá framleiðslukostnaði, að ná honum niður...

Pessi hugsun passar ágætlega við gildi fyrirtækisins sem eru nýsköpun (e. innovation), framleiðni (e. efficiency) og fullkomnun (e. perfection) pó svo að gildin séu ekki ofarlega í huga starfsmanna pegar peir eru spurðir út í pau.

\subsection{Samvinna við viðskiptavini}

Fyrirtækið er með tiltölulega fáa viðskiptavini en hefur jafnframt átt gott samstarf við mjög sterka aðila í sjávarútvegi sem hefur verið lykilatriði fyrir árangur fyrirtækisins. Samvinna við viðskiptavinina er einkennandi pegar horft er til vörupróunar hjá Völku og spila fyrirtæki eins og HB Grandi, Nýfiskur og Samherji par stór hlutverk. Helgi segir erfitt að klára próun á vörunum nema prófa pær í raunverulegum aðstæðum: 
Dú ert að gera eitthvað nýtt með pennan fisk sem er breytilegur, mismunandi gæði og allskonar hlutir pannig að pú getur próað petta ákveðið langt sjálfur en svo parftu að fara með petta í húsin [fiskvinnsluhúsin] og svo klárar pú petta.

Pað er pví mat stjórnenda að forsenda fyrir árangri sé náið samstarf við viðskiptavinina og hefur slíkt samstarf leitt af sér próun og úrbætur á vörunum sem koma sér vel bæði fyrir Völku og viðskiptavini fyrirtækisins. Í pessum tilgangi hafa viðskiptavinirnir verið dregnir að borðinu pegar kemur að rýni á vörunni sem hefur leitt af sér hugmyndir sem Valka hefur getað nýtt sér í framhaldinu.

Раð er einkennandi pegar talað er við stjórnendur og starfsmenn fyrirtækisins að áherslan á viðskiptavininn er mikil og mikið lagt upp úr pví að vinna með honum að farsælustu lausn á hverjum tíma. Samstarfið virðist byggja bæði á tengslaneti frumkvöðulsins en jafnframt byggir pað á tengslaneti annarra starfsmanna. Pannig varð hugmyndin að flokkaranum sem Valka próaði til vegna vinskapar starfsmanns Völku og verksmiðjustjóra hjá viðskiptavininum. Saman unnu vinirnir með hugmyndina og úr varð flokkari sem minnkar yfirvigt í pökkunarferlinu.

Viðskiptavinurinn er ekki bara mikilvægur í próun á vörunni heldur skiptir líka máli að viðskiptavininum gangi vel. Seljanleiki vörunnar byggir á pví að aðrir nái árangri í nýtingu, pannig parf að vera hægt að sýna fram á skilvirkni vörunnar. Að pessu leyti er fyrirtækið háð pví að viðskiptavinirnir nái árangri og séu vel skipulagðir og hefur Valka lagt sig eftir pví að aðstoða viðskiptavini sína til pess að svo megi vera.

Раð er einkennandi að sala á búnaði til eins viðskiptavinar hefur yfirleitt í för með sér að viðkomandi viðskiptavinur verslar meira við fyrirtækið. Laxaverksmiðjan sem seld var til Noregs hefur leitt af sér veruleg viðskipti í pjónustu og öðrum verkefnum fyrir sama kúnna. Pessar tekjur hafa komið sér vel par sem salan getur verið sveiflukennd, eða eins og Matti sagði: „...ef við erum ekki að selja neitt annað pá hefur petta alltaf tikkað inn og hjálpað rekstrinum alveg gríðarlega." Á einhverjum tímapunkti fóru menn út fyrir pá stefnu sem peir höfðu formlega sett sér varðandi pað hvar á markaði peir ætluðu að vera. Рað var búið að ákveða að vera fremur með dýrar vörur í háum gæðum. Engu að síður var tekið verkefni sem stemmdi ekki við pessa stefnu og Einar sagði um petta:,,...mér fannst pað bara ekki góð auglýsing en pessi kúnni keypti síðan skurðarvél af okkur, hann hefði kannski ekkert gert pað ef við hefðum sagt nei..."

Viðskiptavinurinn er alltaf að leita að lausnum á einhverjum vandamálum og Valka reynir eftir fremsta megni að leysa pau. Pannig leiðir eitt verkefni af sér annað sem hefur hugsanlega áhrif á pað með hvaða hætti framvinda stefnunnar er í reynd. Pá hefur umfjöllun um beinaskurðavélina eins og Birgir benti á beint athygli að fyrirtækinu sem hefur leitt til pess að önnur verkefni hafa dottið í hús.

\subsection{Liðsandi}

Pað er mikil liðsvinna og liðsandi í fyrirtækinu sem má merkja af samtölum við starfsmenn og stjórnendur pess. Starfsmenn eru tilbúnir að fórna sér til pess að ná markmiðum sem sett hafa verið og má nefna tilfærslu á sumarfríum og mikla yfirvinnu á álagspunktum sem dæmi um pað hvernig starfsmenn leggja sig fram í pví sambandi. Helgi tekur eftir pessu og segir: „...petta tekur svolítið á pessi vöxtur og menn virðast vera tilbúnir að leggja á sig pegar á parf að halda.“ Helgi leggur að sama skapi áherslu á að mikilvægt sé að viðhalda pessum anda í fyrirtækinu. Starfsmenn vinna saman á jafnréttisgrundvelli, samskipti í tengslum við próun á vörum eru opin pvert á fyrirtækið og í pví samhengi sagði Jónmundur framleiðslustjóri: 
...pú verður að fá fólk til að vinna með pér, bara eins og strákana frammi og sama er með hönnun, pú dregur sem flesta að borðinu til pess að fá pessi input og til pess að mönnum finnist að peir eigi eitthvað í hlutnum, peir séu ekki bara einhverjir, að peir bara vinna hérna, að ná peim hugsunarhætti í burtu, að menn finni að peir eigi eitthvað í pessu.

Frumkvæði starfsmanna er virkjað og áhersla lögð á að starfsmenn finni að peir eigi hlutdeild í pví sem verið er að gera og greina má í samtölum við starfsmenn að samvinna og opin samskipti einkenna menninguna í fyrirtækinu. Til vitnis um pað hafði Martin á orði pegar hann bar saman andrúmsloftið á fyrri vinnustað og pá upplifun sem hann hefur af Völku: „... pað er svo gott samband hér á milli, allir tala svo mikið saman ... maður hefur mikið meiri áhrif á pað sem er að gerast hérna." Starfsmenn upplifa andrúmsloftið jákvætt og skynja andann eins og í fjölskyldu.

\section{8 Ákvarðanatökuferli}

Ákvarðanir eru teknar hratt í fyrirtækinu og finna peir sem hafa unnið fyrir stærri fyrirtæki mikinn mun í pessum efnum. Samkvæmt upplýsingum frá Helga pá tekur stjórn ákvarðanir um allar stærri stefnumótandi aðgerðir en daglegur rekstur er á hans könnu. Starfsmenn upplifa pað pannig að Helgi ákveði hlutina, á stundum finnst peim að hann gæti haft meira samráð við starfsmenn sem að peirra mati mundi skila sér í farsælli niðurstöðu. Á hinn bóginn eru hlutirnir oft á tíðum ræddir og próunarferlið er byggt upp pannig að starfsmenn úr ólíkum deildum fyrirtækisins koma að rýninni og jafnvel er fengin rýni frá birgjum og viðskiptavinum.

Fyrirtækið er mjög sölumiðað og ákvarðanir sem snúa að próun byggja oft á samtölum við viðskiptavinina. Oft er pað samtal milli sölumannsins og viðskiptavinarins sem leiðir af sér frekari próun og sölumaðurinn selur jafnvel einhverja hugmynd sem á eftir að hanna og eins og Matti lýsti pessu ferli: „... og svo verður að leysa pað sko og pað er pá höfuðverkur próunarmannanna og hugbúnaðarmannanna að leysa pað ... en pannig verður bara próun til“.

Tekin var ákvörðun um að innleiða verkefnastjórnunarkerfi sem heitir Kanban og byggir á sjónrænni stjórnun (e. visual management). Ástæðan fyrir valinu á pessu kerfi fremur en öðru lá í pví að Jónmundur pekkti petta kerfi. Рað var byrjað á að setja kerfið upp á töflu par sem petta var hefðbundin sjónræn stjórnun. Рað var aðeins misjöfn upplifun af ágæti pessa tóls með peim hætti en pó pótti mönnum petta almennt vera til bóta miðað við pað sem var áður. Рað mátti skilja pað pannig að áður hafi excel-skjöl og tölvupóstar verið pau verkfæri sem notuð voru til að halda utan um verkefnin. Síðasta sumar var svo ráðinn sumarstarfsmaður sem hafði séð útfærslu á Kanban á tölvutæku formi. Í framhaldinu var byrjað að innleiða tölvuvædda útgáfu af kerfinu sem flestum fannst betra en taflan sem hafði verið áður.

\section{Umræða og niðurstöður}

Við úrvinnslu og umræður um niðurstöður pessarar rannsóknar verður rýnt í sögu, atburðarás og reynslu Völku út frá eftirfarandi nálgun sem byggir á hugmyndum sem hafa kviknað bæði eftir hina fræðilegu yfirferð hér að framan um stefnu í reynd (e. strategy as practice) og pá innsýn í stefnumiðað starf fyrirtækisins Völku sem rannsóknin hefur gefið. Í hinu fræðilega yfirliti hér að framan er dregið saman að áherslan pegar kemur að stefnu í 
reynd sé á pað sem gert er einkum út frá fólkinu, iðkendum stefnunnar, starfsháttunum og síðan iðkuninni, p.e. sjálfri framvindunni á hinu stefnumiðaða starfi. Í pví ljósi hafa höfundar nálgast úrvinnslu rannsóknarinnar með prípættum hætti:

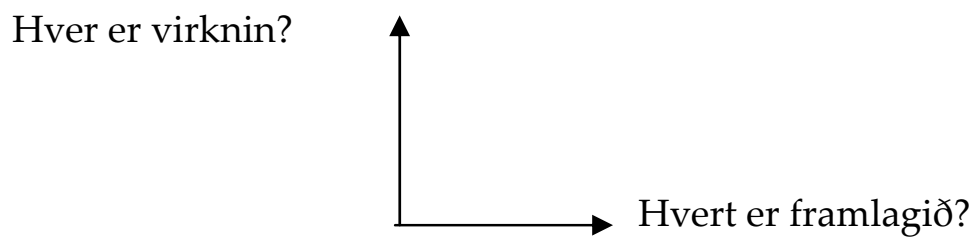

Mynd 2. Virkni og framlag starfsfólks.

Fyrst er horft til iðkenda, p.e. fólksins í fyrirtækinu út frá spurningunum: a) hver er virknin í hinu stefnumiðaða starfi hjá starfsfólki Völku?, með hliðsjón af fjölda starfsmanna og pátttöku peirra í pví stefnumiðaða starfi sem fram fer, og b) hversu mikið framlag til hins stefnumiðaða starfs má rekja til starfsmannanna í heild? Með framlagi er horft til pess sem fram kemur af innleggi eða atburðum sem ýmist skerpa á stefnu eða breyta stefnu fyrirtækisins.

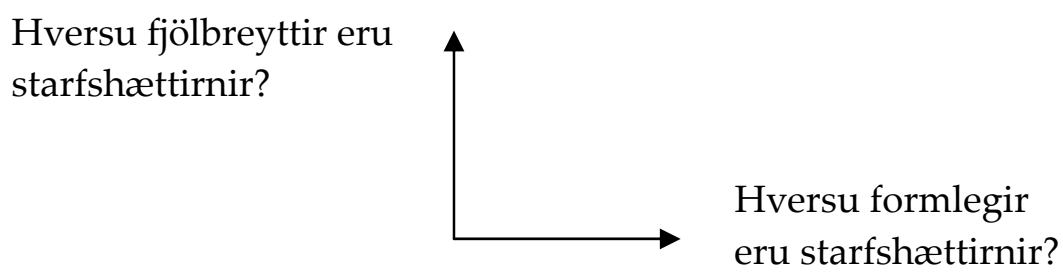

Mynd 3. Fjölbreytni og formfesta starfshátta.

Næsta skref í úrvinnslunni var að horfa til pess hvað rannsóknin sýnir varðandi starfshættina í hinu stefnumiðaða starfi. Við pað er stuðst við eftirfarandi spurningar: c) hversu fjölbreyttir eru starfshættirnir m.t.t. aðferða og verkfæra stefnumótunar sem unnið er með hjá Völku?, og d) hversu formlegir eða óformlegir eru starfshættirnir? Pannig er fjölbreytnin meiri eftir pví sem fleiri aðferðir og verkfæri eru notuð í hinu stefnumiðaða starfi og formfestan meiri eftir pví sem atburðarásin er formbundnari, t.d. í ferli sem kann að vera fastmótað að einhverjum hluta.

Priðja skrefið sneri svo að sjálfri framvindunni í hinu stefnumiðaða starfi í reynd. Par var rannsóknarefnið skoðað út frá spurningunum: e) hver eru umsvifin í starfi fyrirtækisins?, og f) hvert er samspilið við viðskiptavinina í hinu stefnumiðaða starfi? Umsvif voru metin pví meiri sem veltan var hærri og umfang starfseminnar meira. Áhrif samspils og tengsla við viðskiptavini voru metin meiri ef áhrif viðskiptavina á próun og stefnu fyrirtækisins voru sýnileg.

Hver eru umsvifin?

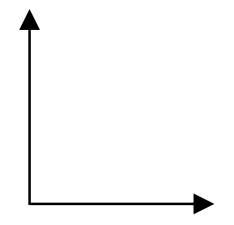

Hvert er samspilið

við viðskiptavini?

Mynd 4. Hver eru umsvif fyrirtækisins og tengsl við viðskiptavini? 
Horft er á atburðarásina í hinu stefnumiðaða starfi út frá tíma, p.e. frá stofnun fyrirtækisins (2003) og par til rannsóknin var gerð (2014). Í myndrænni framsetningu á ofangreindri nálgun er eftir atvikum stuðst við pessi ártöl og fleiri til að lýsa próuninni. Hér að neðan eru rannsóknargögnin skoðuð út frá pessum ofangreindu áföngum

\subsection{Virkni og framlag starfsmanna í stefnumiðuðu starfi}

Við mat á virkni pá var litið til pess hversu virkir starfsmenn virðast vera í starfi og stefnumörkun fyrirtækisins út frá peim fjölda sem tekur pátt í hinu stefnumiðaða starfi. Í upphafi var Helgi einn og var pví virknin mikil, hann var til að byrja með allt í öllu en síðan bættust við fleiri starfsmenn í framleiðsluna sem tóku einnig pátt en pátttaka peirra í hinu stefnumiðaða starfi virðist hafa verið tvímælalaust minni en Helga. Pannig má segja að virknin í heild hafi farið niður á við eftir pví sem starfsfólki fjölgaði í fyrirtækinu fyrst í stað. Pegar fyrirtækið fór í formlega stefnumótunarvinnu var hins vegar leitast við að virkja alla starfsmenn með í ferlinu. Pá hafa stjórnendur sem nýlega voru ráðnir til starfa tekið meiri pátt í umræðu um hvar á markaði fyrirtækið eigi að vera og virðast hafa meiri áhrif á stefnumiðaða próun fyrirtækisins en aðrir starfsmenn. Pannig má segja að virkni pegar kemur að áhrifum á stefnu hafi dalað í kjölfar pess að almennu starfsfólki fjölgaði en að virkni sé vaxandi aftur eftir pví sem millistjórnendum fjölgar hjá fyrirtækinu eins og sjá má á mynd 5 hér fyrir neðan.

Frumkvöðullinn virðist í upphafi hafa verið með nær allt framlag til hins stefnumiðaða starfs. Fyrstu árin pegar fjölgaði í fyrirtækinu virðist framlag annarra starfsmanna ekki bæta miklu við en árið 2007 pegar farið var í formlega vinnu og allir dregnir að borðinu pá má skynja að framlagið aukist, pótt frumkvöðullinn hafi ennpá verið nokkuð miðlægur. Eftir pví sem millistjórnendum hefur fjölgað má sjá merki um að framlag starfsmanna í stefnumiðuðu starfi hafi farið vaxandi. Greina má að millistjórnendur skynja áhrif sín meiri en aðrir starfsmenn sem hafa ekki stjórnunarábyrgð virðast upplifa. Petta er áhugavert par sem menningin einkennist af boðleiðum sem lúta ekki lögmálum skipuritsins. Pannig hafa allir starfsmenn á orði að peir finni ekki áhrif af auknu stigveldi og gildir einu um hvar í skipuritinu starfsmennirnir eru. Раð mátti skynja að frumkvöðullinn væri enn mjög miðlægur og er hægt að túlka pað pannig að dreifing ábyrgðar kunni að vera minni en ætla mætti af stærð fyrirtækisins. Framlag starfsmanna til stefnumiðaðs starfs er sýnilegt í mismunandi birtingarmyndum. Tengslanet peirra gerir pað að verkum að til verða viðskipti sem leiða af sér ákveðna próun eins og í tilfelli Einars og vinar hans í Noregi (Carter o.fl., 2008). Pekking starfsmanna leiðir af sér að ákveðin verkfæri eru valin fremur en önnur eins og í tilfelli Jónmundar og Kanban verkefnastýringarinnar og pá hefur pekking aftur áhrif í formi pess að sumarstarfsmaður próar notkun á verkfærinu sem fellur betur að menningu fyrirtækisins. Parna má einnig sjá hvernig fyrirtæki aðlaga verkfæri í starfi sínu að pörfum sínum óháð pví hver hin skilgreinda notkun er (Jarzabkowski og Wilson, 2006). Mat rannsakenda er að virkni í stefnumiðuðu starfi m.t.t. fjölda starfsmanna hafi dalað eftir pví sem starfsmönnum fjölgaði par sem frumkvöðullinn var mjög miðlægur. Sama má segja um framlagið af sömu ástæðu en hvort tveggja hefur aukist aftur með tilkomu millistjórnenda sem virðast taka meiri pátt í stefnumótandi ákvörðunum en peir sem ekki hafa stjórnunarábyrgð. Sjá má pessa túlkun á mynd 5. 
Virkni

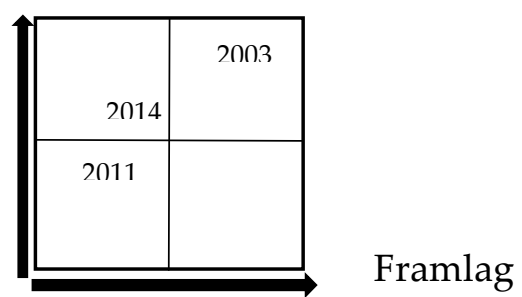

Mynd 5. Próun virkni og framlags starfsfólks til stefnu hjá Völku.

\subsection{Fjölbreytni og formfesta í starfsháttum}

Fjölbreytni í starfsháttum varðandi hið stefnumiðaða starf er frekar lítil í upphafi og hefur að einhverju leyti aukist en pó ekki mikið. Tvisvar sinnum hefur verið haldin vinnustofa til pess að fá alla starfsmenn að stefnumótun félagsins. Vinnustofurnar voru haldnar með fimm ára millibili. Í bæði skiptin stjórnaði Helgi sjálfur vinnunni með starfsmönnum eftir að hafa unnið undirbúningsvinnu með stjórn félagsins. Stefnan hefur í gegnum árin sprottið fram í bland við pessa formlegu stefnumótunarvinnu sem hefur lagt meginlínurnar. Í seinni vinnustofunni var notast við hópaskiptingu og bæði glærur og flettitöflur notaðar til pess að ná fram SVÓT greiningu og delta greiningu á fyrirtækið með aðstoð starfsmanna. Pað má sjá að notkun á verkfærum stefnumótunarfræðanna er ekki samkvæmt bókinni heldur aðlöguð аð pörfum og pekkingu iðkendanna (Jarzabkowski og Wilson, 2006). Ekki voru til gögn um fyrri stefnumótunarfundinn sem hægt var að greina með sambærilegum hætti en samkvæmt peim upplýsingum sem fengist hafa var hann með svipuðum hætti. Helgi stjórnaði umræðunni og undirbjó efnið sem notast var við til grundvallar umræðunni á pessum vinnustofum (Hodgkinson o.fl., 2006) sem veitti honum ákveðið vald (Kaplan, 2011). Svo virðist sem fjölbreytni í starfsháttum tengdum stefnu hafi ekki mikið breyst prátt fyrir fjölgun starfsmanna pótt segja megi að hún hafi aðeins aukist frá pví pegar frumkvöðullinn var einn að störfum (Sjá mynd 6).

Varðandi formfestu í starfsháttum stefnu má segja að hún hafi verið lítil pegar einn maður var allt í öllu; fékk hugmynd, framkvæmdi hana eða tók pær ákvarðanir sem purfti að taka. Smátt og smátt fjölgaði starfsmönnum og pegar fleiri fjárfestar komu inn í myndina varð formfestan aðeins meiri. Stjórnin hefur fjallað um stefnumótun og stefnumótunarvinna með starfsmönnum hefur farið fram. Pegar síðan fagfjárfestar koma inn í myndina er enn meira lagt upp úr formi, stjórn fer að taka pátt í meiriháttar stefnumótandi ákvörðunum og frumkvöðullinn verður ekki eins ráðandi í pví hvert fyrirtækið stefnir pótt áhrif hans séu enn veruleg. Enn í dag spretta pó fram stefnumótandi ákvarðanir sem koma til vegna fyrirspurna frá viðskiptavinum. Pannig hefur bæði formleg og óformleg stefnumótun myndað ákveðinn ramma sem notaður er sem vegvísir en parfir viðskiptavinarins ásamt breytingum á alpjóðamörkuðum hafa áhrif á pað með hvaða hætti stefnumiðuðu starfi fyrirtækisins vindur fram. Рað er sérstaklega áhugavert að sjá hvernig samstarf við viðskiptavininn virðist skipta sköpum varðandi samkeppnishæfni og myndun samkeppnisforskots fyrir fyrirtækið. Раð má segja að nýsköpun, ákveðin heppni og fyrirhyggja hafi átt pátt í pví að mynda petta samkeppnisforskot (Régner, 2008). Formfesta virðist pví fremur lítil pegar kemur að stefnumiðuðu starfi fyrirtækisins pótt greina megi einhverja aukningu, fyrst með tilkomu fleiri fjárfesta og síðar með millistjórnendum. Pannig má glöggt greina að áhrif og völd 
stjórnar og stjórnenda hafa einhver áhrif á hið stefnumiðaða starf pótt fjölbreytnin taki ekki miklum breytingum. (Sjá mynd 6).

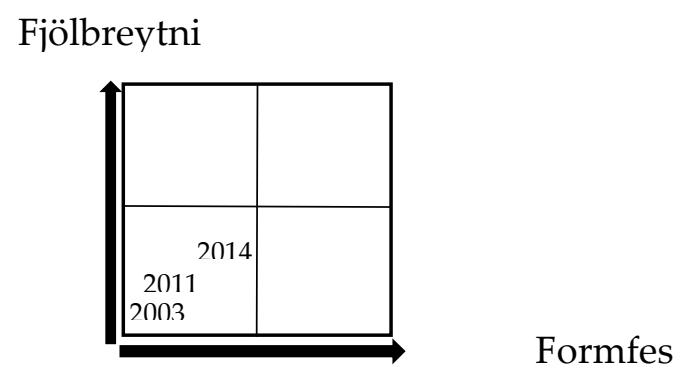

Mynd 6. Próun starfshátta hjá Völku.

\subsection{Umsvif og samspilið við viðskiptavini}

Fyrirtækið Valka hefur stækkað ár frá ári ef frá er talið árið 2012 og pótt fyrirtækið flokkist enn sem lítið, p.e. með veltu undir milljarði á ársgrundvelli og í kringum 20 starfsmenn, pá er pað vaxandi. Prátt fyrir aukin umsvif hafa samskipti og tengsl fyrirtækisins við viðskiptavini verið mikil alveg frá pví að fyrirtækið hóf samstarf við HB Granda árið 2003. Pað má glöggt greina að samtal og samvinna við viðskiptavinina hefur mikil áhrif á stefnumiðað starf. Fyrirtækið leggur áherslu á góða pjónustu við viðskiptavinina sem hefur m.a. leitt til ákvarðana um t.d. að selja ekki bara til landvinnslu heldur einnig vélar í skip. Petta er dæmi um ákvörðun sem hefur ákveðna stefnubreytingu í för með sér og sprettur fram vegna áhrifa frá viðskiptavininum. Slík ákvörðun hefur í för með sér að pað parf að gera breytingar á skipulagi pjónustu til pess að geta sinnt viðskiptavininum í samræmi við pá stefnu sem fyrirtækið hefur, p.e. að viðskiptavinurinn sé alltaf sáttur. Ákvörðunin er tekin án pess að hún sé hugsuð sem stefnumótandi ákvörðun en í raun er hún pað (Égels-Zandén og Rosén, 2014). Petta samspil við viðskiptavininn hefur áhrif á stefnu og stefnan breytist eftir pví sem parfir viðskiptavinarins breytast yfir tíma. Sjá má túlkun rannsakenda á samspili umsvifa og tengsla við viðskiptavina í mynd 7 hér fyrir neðan.

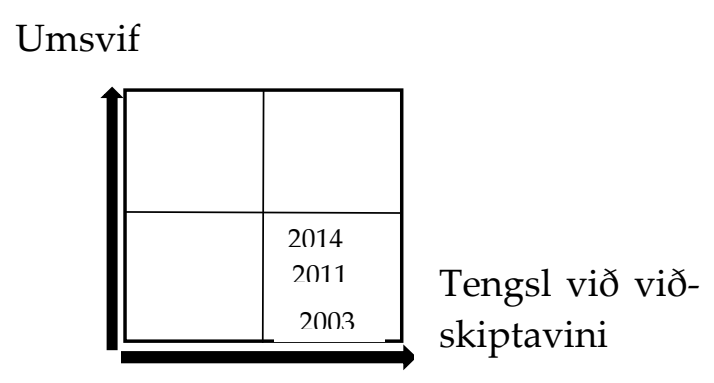

Mynd 7. Próun umsvifa og tengsla við viðskiptavini hjá Völku.

\subsection{Stefna í reynd - Próun og stada}

Stefna Völku hefur próast á pann veg að verða afmarkaðri og skýrari eftir pví sem árin líða. Til að byrja með var fyrirtækið með meiri kraft í hugbúnaðarpróun og hugbúnaðarsölu en í dag setur pað krafta sína í að próa og selja vélar í fiskvinnslu sem byggja á fremur flóknum hugbúnaði. Раð er ljóst að framvinda stefnu í fyrirtækinu hefur miðað í senn að vexti og sérhæfingu með áherslu á pað sem í dag má kalla kjarnastarfsemi fyrirtækisins. Pessi stefna 
virðist skýr pví að fyrirtækið hefur haldið stefnunni prátt fyrir erfitt árferði eins og sjá má á árinu 2012 pegar veltan datt niður en starfsmönnum hélt áfram að fjölga. Pá má greina hvernig efnahagshrunið árið 2008 hafði áhrif á stefnu fyrirtækisins. •að breytti kannski ekki grunnhugmyndinni sem var að vera alpjóðlegt hátæknifyrirtæki eins og sjá má á valinu á nafninu strax í upphafi og á pátttöku í alpjóðlegum sýningum, en hrunið hafði pau áhrif að sótt var á erlendan markað fyrr en ella. Pannig má sjá samspil pess sem gerist í hinu stóra samhengi við pað sem gerist á vettvangi fyrirtækisins og hvernig pað hefur áhrif á hvernig stefnu fyrirtækisins vindur fram (Whittington, 2006).

Pá er áhugavert að sjá að mörg af peim atriðum sem komu fram í formlegri stefnumótunarvinnu með starfsmönnum eru í ákveðnum farvegi eða hafa verið innleidd að einhverju marki. Starfsmenn skynja pað hins vegar ekki með peim hætti af pví að eftirfylgnin hefur ekki verið skipulega sýnileg starfsmönnum. Hugsanlega er sambandið líka pannig аð раð sem kom fram í stefnumótunarvinnunni eru brýnustu verkefnin og slík verkefni eru í vinnslu, óháð pví hvort pau eru rædd í formlegri stefnumótunarvinnu eða ekki.

\section{Framlag og frekari rannsóknir}

Stefna í reynd er enn að slíta barnskónum sem skóli í stefnumótunarfræðunum pótt rannsóknir og fræðileg skrif á pessum nótum hafi aukist síðustu ár. Rannsókn höfunda er í senn leitandi og lýsandi varðandi pað hvernig megi draga fram lykilatriðin í raun við mótun stefnu, framvindu hennar og próun lítils fyrirtækis yfir tíma.

Rýnt hefur verið í rannsóknargögnin út frá pætti iðkenda, starfsháttum og iðkuninni sjálfri, p.e. framvindu hins stefnumiðaða starfs í reynd. Pessu samspili má lýsa í eftirfarandi líkani sem höfundar hugsa sér að próa nánar í frekari rannsóknum:

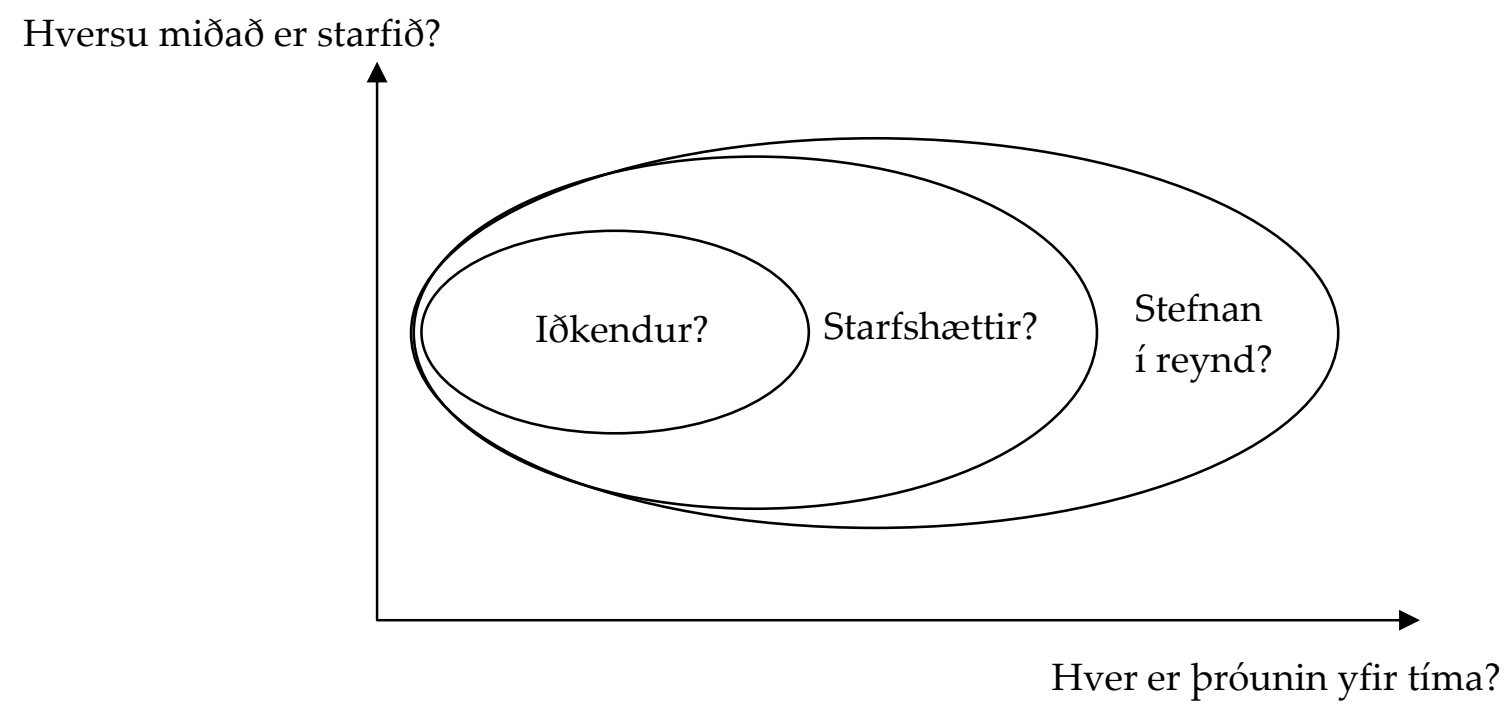

Mynd 8. Líkan af samspili iðkenda, starfshátta og iðkunar stefnu.

Með líkaninu eru dregin saman í eina mynd pað sem nefna má sem kjarnaatriðin í stefnu í reynd. Samantektin byggir bæði á hinni fræðilegu umræðu og peirri rannsókn sem gerð hefur verið. Ekki síst er horft til peirrar nálgunar sem beitt var við úrvinnslu rannsóknarinnar. Раð er grundvallaratriði að stefnan kemur fram í pví sem gert er í 
fyrirtækinu. Í aðalhlutverkinu eru gerendur hins stefnumiðaða starfs, iðkendurnir. Hvað gera peir og hversu virkir eru peir? Hvert er framlag peirra til stefnunnar og hversu stefnumiðað er starfið? Hversu miðað starfið er birtist í rásfestu fyrirtækisins yfir tíma eða tímabil. Varðandi starfshættina er átt við pað munstur athafna sem á sér stað í samspili starfsmannanna og tengist hinu stefnumiðaða starfi. Hver er fjölbreytnin og formfestan í starfsháttunum? Hvert er framlag peirra til mögulegrar skerpingar og breytinga á stefnu með hliðsjón af próun yfir tíma? Varðandi sjálfa stefnuna pá er áherslan á birtingarmynd athafna fyrirtækisins. Hver er pessi birtingarmynd gegnum umsvif og árangur fyrirtækisins almennt séð? Petta líkan er á frumstigi og er sett fram með fyrirvara um frekari rannsóknir. Pví er fyrst og fremst ætlað að auðvelda yfirsýnina yfir kjarnaatriðin í peirri fræðilegu nálgun sem stefna í reynd er.

Ef litið er til fyrirtækisins í rannsókninni sem gerð var pá má glöggt greina út frá samtölum við starfsmenn og stjórnendur Völku, sem ótvírætt hafa verið virkir pátttakendur, að stefna fyrirtækisins hefur mótast með bæði áformuðum og sjálfsprottnum hætti í samspili yfir tíma. Pegar horft er til framvindu stefnunnar má greina að skerpan hefur aukist eftir pví sem fyrirtækið hefur stækkað. Starfshættir í hinu stefnumiðaða starfi bera hins vegar einkenni lítillar formfestu og lítillar fjölbreytni sem skýra má með lítilli stærð fyrirtækisins sem rannsakað var. Раð má greina að formleg stefnumótunarvinna skilaði sér inn í stefnumiðað starf fyrirtækisins og áhrif viðskiptavina á framvindu hins stefnumiðaða starfs eru ótvíræð. Tengslin við viðskiptavini eru mikil og oft afgerandi fyrir stefnu fyrirtækisins yfir tiltekin tímabil. Рað má pví spyrja sig um pátt viðskiptavina sem gerenda eða iðkenda í hinu stefnumiðaða starfi.

Við höfum hér að ofan, í umræðum um niðurstöður og í samantektinni, gefið mynd af pví með hvaða hætti stefna Völku hefur myndast og próast yfir pann tíma sem fyrirtækið hefur starfað og pað væri áhugavert að fylgja fyrirtækinu eftir og sjá hvernig pví vegnar í framtíðinni.

\subsection{Framlag til fræðanna, takmarkanir og næstu skref}

Við úrvinnslu á pví hvernig megi rýna í stefnu fyrirtækis í reynd, p.e horfa á samspil iðkenda, starfshátta og iðkunar stefnu í fyrirtækinu Völku, hafa höfundar sett fram tiltekna útfærslu á pví hvernig rannsakendur geta varpað ljósi á stefnumiðað starf fyrirtækja út frá stefnu í reynd. Pessi útfærsla eða líkan er vissulega nokkur einföldun á pví hvernig megi lýsa próun á stefnu fyrirtækis yfir tíma og hvaða pættir hafi áhrif á pá próun. Nauðsynlegt er að útfæra pessa nálgun frekar og rýna hana nánar með hliðsjón af fræðunum sem vikið hefur verið að í greininni.

Rannsóknin leiddi einnig ýmislegt áhugavert í ljós sem full ástæða er að gera að sérstöku rannsóknarefni. Раð kom fram að gildi fyrirtækisins eru ekki ofarlega í huga starfsmanna og pví væri áhugavert að skoða sérstaklega með hvaða hætti gildi verða til og eru notuð í íslenskum fyrirtækjum og stofnunum, stórum sem smáum. Pá væri áhugavert að skoða opinberan rekstur á Íslandi út frá stefnu í reynd og einnig væri áhugavert að skoða betur samspil stefnu, mælikvarða og markmiða. Р.e. með hvaða hætti hvatar hafa áhrif á framlag starfsmanna í stefnumiðuðu starfi. Pá væri verðugt verkefni að finna skýrari viðmið og mælikvarða í peirri nálgun sem notuð var við umræðu um niðurstöður rannsóknarinnar sem hér hefur verið gerð , p.e. í fimmta kafla hér að framan.

Aðalmarkmiðið með greininni var að opna fyrir umræðu um stefnu í reynd varðandi stefnumiðað starf hér á Íslandi. Рað er von höfunda að greinin skili pví og ýti undir áhuga annarra fræðimanna og efli fræðilega umræðu á pessu sviði. Takmarkandi páttur í 
rannsókninni er að hún afmarkast við eitt fyrirtæki sem gerir pað að verkum að niðurstöðurnar endurspegla einungis hvernig samspil iðkenda, starfshátta og iðkunar stefnu er hjá pessu einstaka fyrirtæki. Рað hefði mátt skýra betur aðkomu stjórnar með pví að ræða við fulltrúa úr stjórninni og er líklegt að pað hefði bætt rannsóknina. Pá takmarkaðist rannsóknin af pví að tíminn var takmarkaður og pörf er á rannsókn sem spannaði lengri tíma par sem rannsakendur fengju að fylgjast með starfsemi fyrirtækis frá degi til dags. Höfundar sjá ótvíræða pörf á frekari rannsóknum á stefnu og stefnumiðuðu starfi í íslenskum fyrirtækjum, ekki síst með pessari nálgun, og að pað geti aukið verulega við pekkingu á stefnumiðuðu starfi hérlendis. Sú rannsókn sem hér hefur verið greint frá er pví hugsuð sem upphaf en ekki endapunktur á rannsóknum sem ætlað er að varpa ljósi á pað hvernig samspil iðkenda, starfshátta og iðkunar stefnu er í íslenskum fyrirtækjum.

\section{Heimildaskrá}

Avram, D. og Kuhne, S. (2008). Implementing responsible business behavior from a strategic management perspective: Developing a framework for Austrian SMEs. Journal of Business Ethics, 82(2), 463-475.

AVS. (2009). Bylting í pökkun og flokkun á ferskum laxaflökum. Sótt 19. júní 2014 af http://www.avs.is/frettir/2009/10/30/nr/1946.

Balogun, J., Huff, A. og Johnson, P. (2003). Three responses to the methodological challenges of studying strategizing. Journal of Management Studies, 40(1), 197-224.

Balogun, J., Jarzabkowski, P. og Vaara, E. (2011). Selling, resistance and reconciliation: A critical discursive approach to subsidiary role evolution in MNEs. Journal of International Business Studies, 42, 765-786.

Carroll, B., Levy, L. og Richmond, D. (2008). Strategy as practice: Challenging the competency paradigm. Leadership, 4(4), 363-379.

Carter, C., Clegg, S. og Kornberger, M. (2008). Strategy as practice? Strategic Organization, 6(1), 83-99.

Chia, R. Og MacKay, B. (2007). Post-processual challenges for the emerging strategy-aspractice perspective: Discovering strategy in the logic of practice. Human Relations, 60(1), 217-242.

Corradi, G., Gherardi, S. og Verzelloni, L. (2010). Through the practice lens: Where is the bandwagon of practice-based studies heading? Management Learning, 41(3), 265-283.

Creswell, J.W. (2013). Qualitative inquiry \& research design: Choosing among five approaches (3. útgáfa). Thousand Oaks: Sage Publications.

Dyer, G. og Wilkins, A. (1991). Better stories, not better constructs to generate better theory: A rejoinder to Eisenhardt. Academy of Management Review, 16(3), 613-619.

Egels-Zandén, N. og Rosén, M. (2014). Sustainable strategy formation at a Swedish industrial company: Bridging the strategy-as-practice and sustainability gap. Journal of Cleaner Production, 96(1), 139-147.

Eisenhardt, K. (1989). Building theories from case study research. The Academy of Management Review, 14(4), 532-550.

Ericson, M. (2014). On the dynamics of fluidity and open-endedness of strategy process toward a strategy-as-practicing conceptualization. Scandinavian Journal of Management, $30,1-15$. 
Flyvbjerg, B. (2006). Five misunderstandings about case-Study research. Qualitative Inquiry, 12(2), 219-245.

Gibbert, M., Ruigrok, W. og Wicki, B. (2008). What passes as a rigorous case study? Strategic Management Journal, 29, 1465-1474.

Giraudeau, M. (2008). The drafts of strategy: Opening up plans and their uses. Long Range Planning, 41, 291-308.

Golsorkhi, D., Rouleau, L., Seidl, D. og Vaara, E. (2010). Cambridge handbook of strategy as practice. New York: Cambridge University Press.

Gomez, M. og Bouty, I. (2011). The emergence of an influential practice: Food for thought. Organization Studies, 32(7), 921-940.

Helgi Hjálmarsson (2013). Helgi Hjálmarsson með kynningu á Völku 1. Hluti-Verkfræðingafélag Íslands. Sótt 15. ágúst 2014 af vef http://www.youtube.com/watch?v=FLP_xL-z9yY.

Hendry, K., Kiel, G. og Nicholson, G. (2010). How boards strategise: A strategy as practice view. Long Range Planning, 43, 33-56.

Hendry, J. og Seidl, D. (2003). The structure and significance of strategic episodes: Social systems theory and the routine practices of strategic change. Journal of Management Studies, 40(1), 175-196.

Heracleous, L og Jacobs, C. (2008). Crafting strategy: The role of embodied metaphors. Long Range Planning, 41, 309-325.

Hodgkinson, G., Whittington, R., Johnson, G. og Schwarz, M. (2006). The role of strategy workshops in strategy development processes: Formality, communication, co-ordination and inclusion. Long Range Planning, 39, 479-496.

Jarratt, D. og Stiles, D. (2010). How are methodologies and tools framing managers' strategizing practice in competitive strategy development? British Journal of Management, 21(1), 28-43

Jarzabkowski, P. (2003). Strategic practices: An activity theory perspective on continuity and change. Journal of Management Studies 40(1), 23-54.

Jarzabkowski, P. (2004). Strategy as practice: Recursiveness, adaptation, and practices-in-use. Organization Studies, 25(4), 529-560.

Jarzabkowski, P. og Balogun, J. (2009). The practice and process of delivering integration through strategic planning. Journal of Management Studies, 46(8), 1255-1288.

Jarzabkowski, P., Balogun, J. og Seidl, D. (2007). Strategizing: The challenges of a practice perspective. Human Relations, 60(1), 5-27.

Jarzabkowski, P. og Seidl, D. (2008). The role of meetings in the social practice of strategy. Organization Studies, 29(11), 1391-1426.

Jarzabkowski, P. og Spee, A.P. (2009). Strategy-as-practice: A review and future directions for the field. International Journal of Management Reviews, 11(1), 69-95.

Jarzabkowski, P. og Wilson, D. (2006). Actionable strategy knowledge: A practice perspective. European Management Journal, 24(5), 348-367.

Johansson, R. (2003). Case study methodology. Fyrirlestur fluttur á ráðstefnu Methodologies in Housing Research sem haldin var 22-24 september af Royal Institute of Technology, Stokkhólmi.

Johnson, G., Langley, A., Melin, L. og Whittington, R. (2007). Strategy as practice: Research directions and resources. New York: Cambridge University Press.

Kaplan, S. (2011). Strategy and PowerPoint: An inquiry into the epistemic culture and machinery of strategy making. Organization Science, 22(2), 320-346. 
Küpers, W., Mantere, S. og Statler, M. (2013). Strategy as storytelling: A phenomenological collaboration. Journal of Management Inquiry, 22(1), 83-100.

Laine, P. og Vaara, E. (2007). Struggling over subjectivity: A discursive analysis of strategic development in a group. Human Relations, 60(1), 29-58.

Mantere, S. (2005). Strategic practices as enablers and disablers of championing activity. Strategic Organization, 3(2), 157-184.

Mantere, S. og Vaara, E. (2008). On the problem of participation in strategy: A critical discursive perspective. Organization Science, 19(2), 341-358.

McCabe, D. (2010). Building society strategy-as-power: Ambiguity, contradiction and the exercise of power in a UK. Organization, 17(2), 151-175.

Meyer, C. (2001). A case in case study methodology. Field Methods, 13(4), 329-352.

Mintzberg, H. (1994). The fall and rise of strategic planning. Harvard Business Review, janúarfebrúar, 107-114.

Moisander, J. og Stenfors, S. (2009). Development and use exploring the edges of theorypractice gap: Epistemic cultures in strategy-tool. Organization, 16(2), 227-247.

Noor, K. (2008). Case study: A strategic research methodology. American Journal of Applied Sciences, 5(11), 1602-1604.

Nordqvist, M. og Melin, L (2010). The promise of the strategy as practice perspective for family business strategy research. Journal of Family Business Strategy, 1, 15-25.

Ocasio, W. og Rise, J. (2008). Rise and fall - or transformation? The evolution of strategic planning at the general electric company, 1940-2006. Long Range Planning, 41, 248-272.

Rasche, A. og Chia, R. (2009). Researching strategy practices: A genealogical social theory perspective. Organization Studies, 30(07), 713-734.

Reckwitz, A. (2002). Toward a theory of social practices A development in culturalist theorizing. European Journal of Social Theory, 5(2), 243-263.

Regnér, P. (2003). Strategy creation in the periphery: Inductive versus deductive strategy making. Journal of Management Studies, 40(1), 57-82.

Regnér, P. (2008) Strategy-as-practice and dynamic capabilities: Steps towards a dynamic view of strategy. Human Relations, 61(4), 565-588.

Rouleau, L. og Balogun, J. (2011). Middle managers, strategic sensemaking, and discursive competence. Journal of Management Studies, 48(5), 953-983.

Sage, D., Dainty, A. og Brookes, N. (2012). A 'strategy-as-practice'exploration of lean construction strategizing. Building Research and Information, 40(2), 221-230.

Samtök iðnaðarins (2012). Valka hlýtur vaxtarsprotann 2012. Sótt 19. júní 2014 af http://www.si.is/starfsgreinahopar/sprotafyrirtaeki/frettir-og-greinar/nr/9428.

Schatzki, T. (2006). On organizations as they happen. Organization Studies, 27(12), 1863-1873.

Splitter, V. og Seidl, D. (2011). Does practice-based research on strategy lead to practically relevant knowledge? Implications of a Bourdieusian perspective. The Journal of Applied Behavioral Science, 47(1), 98-120.

Spee, P. og Jarzabkowski, P. (2011) Strategic planning as communicative process. Organization Studies, 32(9), 1217-1245.

Stonehouse, G. og Pemberton, J. (2002). Stragetic planning in SEM's - some emirical findings. Management Decision, 40(9), 853-861.

Vaara, E. og Whittington, R. (2012). Strategy and practice: Taking social practices seriously. Academy of Management Annals, 6(1), 285-336.

Valka. (e.d.) About Valka. Sótt 19. júní 2014 af http://www.valka.is. 
Welch, C., Piekkari, R., Plakoyiannaki, E. og Paavilainen-Mantymaki E. (2011). Theorising from case studies: Towards a pluralist future for international business research. Journal of International Business Studies, 42, 740-762

Venkateswaran, R. og Prabhu, G. (2010). Taking stock of research methods in strategy-aspractice. The Electronic Journal of Business Research Methods, 8(2), 156-162.

Vigfús Hallgrímsson (2014). Stefnumótun i leit að skilningi, samvinnu og gæðum: stefnumótunarfrásaga opinbers fulltrúa á aðalnámskrá grunnskóla. Reykjavík, Háskóli Íslands.

Whittington, R. (1996). Strategy as practice. Long Range Planning, 29(5), 731-735.

Whittington, R. (2006). Completing the practice turn in strategy research. Organization Studies, 27(5), 613-634.

Whittington, R. (2007). Strategy practice and strategy process: Family differences and the sociological eye. Organization Studies, 28(10), 1575-1586.

Yin, R. (1981). The case study crisis: Some answers. Administrative Science Quarterly, 26, 58-65.

Yin, R. (1991). Case study research: Design and methods. Newbury Park, CA: Sage Publications.

Yin, R. (2009). Case study research. Thousand Oaks, CA: Sage.

Zainal, Z. (2007). Case study as a research method. Jurnal Kemanusiaan, 9, 1-6. 